\title{
ARAŞTIRMA/RESEARCH
}

\section{Mianserin'in sıçanlarda streptozotosin ile indüklenen hiperglisemi ve metabolik değişiklikler üzerine etkisi}

Effect of mianserin on streptozotocin-induced hyperglycemia and metabolic alterations in rats

Özgür Devrim Can ${ }^{1}$, Umut İrfan Üçel ${ }^{1}$, Ümide Demir Özkay ${ }^{1}$, Miriş Dikmen²

${ }^{1}$ Anadolu Üniversitesi, Eczacılık Fakültesi, Farmakoloji Anabilim Dalı, ${ }^{2}$ Klinik Eczacılık Anabilim Dalı, Eskişehir, Turkey

\begin{abstract}
Cukurova Medical Journat 2
Abstract

Purpose: The aim of this study was to investigate possible effects of atypical antidepressant mianserin on glycemia levels and metabolic parameters of normoglycemic and diabetic rats.
\end{abstract}

Material and Methods: Effects of mianserin administration on blood glucose levels in rats were assessed by measuring "fasting blood glucose", "glycosylated haemoglobin" levels and conducting the "oral glucose tolerance test". Changes in metabolic parameters such as food and water consumption and urine and faeces excretion were observed using metabolic cages. Results: Administration of mianserin for 7 and 14 days at doses of 30 and $45 \mathrm{mg} / \mathrm{kg}$ significantly reduced the hyperglycemia and elevated HbA1c levels; also improved hyperglycemia induced polydipsia, polyuria, polyphagia, and increased faeces amounts. Mianserin, at both of the administrated doses, reduced the weight loss observed in diabetic animals. With regard to the anti-hyperglycaemic effect, mianserin administered at a dose of $30 \mathrm{mg} / \mathrm{kg}$ was found to be as effective as the reference drug metformin (dose, $1 \mathrm{~g} / \mathrm{kg}$ ).

Conclusion: This study showed that the antihyperglycemic effect of mianserin, an atypical antidepressant, was comparable to those of the reference drug metformin. However, the pharmacological mechanisms underlying this anti-hyperglycemic effect of mianserin remain to be elucidated.

Key words: Diabetes mellitus, HbA1c, metabolic cage, metformin, mianserin, streptozotocin

\section{Öz}

Amaç: Bu çalışmada, atipik bir antidepresan olan mianserin'in normoglisemik ve diyabetik sıçanlarda glisemi düzeyi ve metabolik parametreler üzerine olası etkilerinin araştırılması amaçlanmıştır.

Gereç ve Yöntem: Mianserin'in subakut uygulamasının, streptozotosin (STZ) ile diyabet oluşturulmuş sıçanların kan glukoz seviyeleri üzerine etkileri, "açlık kan glukozu ölçümleri”, "glikozile hemoglobin ölçümleri” ve “oral glukoz tolerans testi" ile değerlendirilmiştir. Yem ve su tüketimi, idrar ve dışkı atılımı gibi metabolik parametrelerin değişimi ise metabolik kafes düzenekleri ile izlenmiştir.

Bulgular: Mianserin'in 30 ve $45 \mathrm{mg} / \mathrm{kg}$ dozlarda 7 ve 14 gün süre uygulamasının diyabetik sıçanlardaki hiperglisemiyi ve artmış HbA1c düzeylerini azalttığı; söz konusu hiperglisemiye bağlı olarak gelişen polidipsiyi, poliüriyi, polifajiyi ve dıșkı atılımındaki artışı anlaml biçimde düzelttiği belirlenmiştir. Mianserin uygulandığ iki dozda da divabetik hayvanların vücut ağırlıklarındaki kaybı azaltmıştır. Antihiperglisemik etki açısından mianserin'in $30 \mathrm{mg} / \mathrm{kg}$ dozu referans ilaç metformin $(1 \mathrm{~g} / \mathrm{kg}) \mathrm{kadar}$ etkili bulunmuştur.

Sonuç: $\mathrm{Bu}$ çalışma ile atipik bir antidepresan olan mianserin'in metformin ile kiyaslanabilir ölçüde antihiperglisemik etkinlik gösterdiği ortaya konulmuştur. Bununla birlikte, mianserin'in antihiperglisemik etkinliğinin altında yatan farmakolojik mekanizmalar aydınlatılmayı beklemektedir.

Anahtar kelimeler: Diabetes mellitus, HbA1c, metabolik kafes, metformin, mianserin, streptozotosin 


\section{GİRİ̧̧}

Diabetes mellitus (DM) karbonhidrat, yağ ve protein metabolizmalarında bozukluklarla karakterize, yüksek plazma glukoz seviyeleriyle seyreden kronik bir hastalıktır ${ }^{1}$. Diyabet hastalarında plazma glukoz düzeylerinin uygun tedavi ile kontrol altına alınmadığı durumlarda yaşamı tehdit edebilecek ölçüde önemli olabilen "akut" ve uzun süren metabolik düzensizlikler nedeniyle çeşitli sistem, organ veya dokularda hasarlara neden olan "kronik" komplikasyonlar ortaya çıkabilmektedir ${ }^{2,3}$.

Tip I ve tip II DM'li hastalarda yapilan çalışmalar insülin işlevlerindeki bozulmanın ve kronik hipergliseminin MSS komplikasyonlarının gelişimi; çeşitli nörodejeneratif hastalıkların ve duygu durum hastalıklarının oluşumu açısından patolojik önemi olduğunu ortaya koymuş ve 'diyabetik ensefalopati’ DM'nin bir komplikasyonu olarak rapor edilmiştir-6.

Antidepresanlar diyabetik hastalarda insidans yüksek olan duygu-durum bozukluklarının ve nöropatik ağrının tedavisi için sıklıkla kullanılan ilaçlardır. Yapılan çalışmalar, diyabetik hastalarda söz konu endikasyonlar için kullanılan antidepresanların hastaların kan glukoz seviyelerini etkilediğine ve diyabetik hastalarda glisemik kontrolün bozulmasına neden olabildiğine işaret etmektedir. Diyabetik hastalarda depresyon tedavisi için başlanan bazı ilaçların hipoglisemik etki gösterdiğine $e^{7-10}$ işaret eden çalışmaların yanı sıra antidepresan kullanımına bağlı hiperglisemi gelişimini bildiren raporlar da bulunmaktadır ${ }^{11-12}$. Bu bilgilerden hareketle, antidepresan ilaçların kan glukozu üzerine potansiyel etkilerinin deneysel diyabet modellerinde araştırılması klinik açıdan önem taşımaktadır.

Mianserin, çeşitli ülkelerde major depresyon tedavisi için onaylanmış tetrasiklik yapılı bir ilaçtır. $\mathrm{Bu}$ ilacın antidepresan etkisinin presinaptik, oto- ve hetero- $\alpha_{2-}$ adrenoreseptörlerin blokaj1 sonucu noradrenerjik ve serotonerjik nörotransmisyondaki artış ile ilişkili olduğu kabul edilmektedir ${ }^{13,14}$. Mianserin'in antidepresan etkinliğinin yanı sıra analjezik etkinliğe de sahip olduğu rapor edilmiştir ${ }^{15,16}$. Ancak, literatürde bu ilacın normoglisemik ya da hiperglisemik koşullarda kan glukozu üzerine etkilerine ilişkin detaylı bir deneysel araştırmaya rastlanmamıştır.

$\mathrm{Bu}$ çalışmada antidepresanların glisemi üzerine etki potansiyelinden yola çıkılarak, atipik bir antidepresan olan mianserin'in normoglisemik ve diyabetik sıçanlarda kan glukozu ve ilişkili metabolik parametreler üzerine olası etkilerinin araştırılması amaçlanmıştır.

\section{GEREÇ VE YÖNTEM}

\section{Deney hayvanları}

Çalışmalarda aynı yaşta 250-300 gr ağılıl̆ğında erkek Wistar sıçanlar kullanılmıştır. Deneylerde kullanilan hayvanlar 12 saat karanlık 12 saat aydınlık döngüsünde (ş̧ılar $8^{00}-20^{00}$ arasında açılmaktadır), $\quad 24 \pm 1^{\circ} \mathrm{C}$ sicaklıktaki iyi havalandırılan odalarda bulundurulmuş ve standart hayvan yemi ile beslenmişlerdir. $\mathrm{Bu}$ çalışmanın deneysel protokolü Anadolu Üniversitesi Hayvan Deneyleri Yerel Etik Kurulu'nun 5.4.2011 tarihli ve 9-11 numaralı kararı ile onaylanmıştır.

\section{Kullanilan kimyasal maddeler}

$\mathrm{Bu}$ çalışmada kullanılan streptozotosin (STZ), mianserin hidroklorür, metformin hidroklorür, pregabalin, morfin sülfat ve nalokson hidroklorür Sigma (St. Louis, MO, ABD)'dan; sitrik asit, trisodyum sitrat ve etanol Merck (Darmstadt, Almanya)'dan; serum fizyolojik ise Adeka (Samsun, Türkiye)'dan satın alınmıştır. Ketamin ve ksilazin için sırasıyla Alfamine ${ }^{\circledR}$ ve Alfazyne ${ }^{\circledR}$ preparatları kullanılmıştır.

\section{Deneysel diyabetin oluşturulması}

Diyabet oluşturulacak sıçan grupları bir gece aç bırakıldıktan sonra kuyruk venlerinin içine 50 $\mathrm{mg} / \mathrm{kg}$ tek doz STZ uygulanmıştır ${ }^{17}$. Uygulanan STZ, $\mathrm{pH}=4.5,0.1 \mathrm{M}$ sitrat tamponu içerisinde 
hazırlanmıştır. STZ enjeksiyonundan sonra hiperinsülinemiyi ve hipoglisemik şoku azaltmak ve/veya önlemek amacıyla sıçanların bulunduğu kafeslere $5 \mathrm{mmol} / \mathrm{L}$ glukoz solüsyonu içeren suluklar yerleştirilmiştir ${ }^{18}$.

Enjeksiyon yapıldıktan 72 saat sonra alınan kan


İsviçre) ile kan şekeri ölçümleri yapılmıştır. Kan glukoz düzeyi $300 \mathrm{mg} / \mathrm{dL}$ üzerinde olan hayvanlar diyabetik olarak kabul edilmiştir. Diyabetik sıçanların kontrolü olarak kullanılan tüm sağlıklı sıçanlara i.v olarak aynı hacimde sitrat tamponu enjekte edilmiştir ${ }^{19}$.

\section{Deney gruplarının oluşturulması}

Subakut uygulama yapılan normoglisemik deney grupları aşağıdaki biçimde oluşturulmuştur:

\begin{tabular}{|c|c|}
\hline $\begin{array}{l}\text { Kontrol } \\
\text { grubu }\end{array}$ & $\begin{array}{l}14 \text { gün süre ile serum fizyolojik } \\
\text { uygulanan grup }\end{array}$ \\
\hline $\begin{array}{l}\text { MNS-30 } \\
\text { grubu }\end{array}$ & $\begin{array}{l}14 \text { gün süre ile } 30 \mathrm{mg} / \mathrm{kg} \\
\text { mianserin } 20 \text { uygulanan grup }\end{array}$ \\
\hline $\begin{array}{l}\text { MNS-45 } \\
\text { grubu }\end{array}$ & $\begin{array}{l}14 \text { gün süre ile } 45 \mathrm{mg} / \mathrm{kg} \\
\text { mianserin uygulanan grup }\end{array}$ \\
\hline
\end{tabular}

Subakut uygulama yapılan diyabetik deney grupları ise aşağıdaki biçimde oluşturulmuştur:

\begin{tabular}{|c|c|}
\hline $\begin{array}{l}\text { Kontrol } \\
\text { (Normoglise } \\
\text { mik) grubu }\end{array}$ & $\begin{array}{l}\text { İ.v sitrat tamponu enjekte edilen } \\
\text { ve enjeksiyondan } 4 \text { hafta sonra } 14 \\
\text { gün süre ile serum fizyolojik } \\
\text { uygulanan grup }\end{array}$ \\
\hline DM grubu & $\begin{array}{l}\text { İ.v STZ enjekte edilen ve } \\
\text { enjeksiyondan } 4 \text { hafta sonra } 14 \\
\text { gün süre ile serum fizyolojik } \\
\text { uygulanan grup }\end{array}$ \\
\hline $\begin{array}{l}\text { Metformin+ } \\
\text { DM grubu }\end{array}$ & $\begin{array}{l}\text { I.v STZ enjekte edilen ve } \\
\text { enjeksiyondan } 4 \text { hafta sonra } 14 \\
\text { gün süre ile günde iki kez } 500 \\
\text { mg/kg metformin } 21 \text { uygulanan } \\
\text { grup }\end{array}$ \\
\hline $\begin{array}{l}\text { MNS- } \\
30+\mathrm{DM} \\
\text { grubu }\end{array}$ & $\begin{array}{l}\text { İ.v. STZ enjekte edilen ve } \\
\text { enjeksiyondan } 4 \text { hafta sonra } 14 \\
\text { gün süre ile } 30 \mathrm{mg} / \mathrm{kg} \text { mianserin } \\
\text { uygulanan grup }\end{array}$ \\
\hline $\begin{array}{l}\text { MNS- } \\
45+\mathrm{DM} \\
\text { grubu }\end{array}$ & $\begin{array}{l}\text { I.v. STZ enjekte edilen ve } \\
\text { enjeksiyondan } 4 \text { hafta sonra } 14 \\
\text { gün süre ile } 45 \mathrm{mg} / \mathrm{kg} \text { mianserin } \\
\text { uvgulanan grup }\end{array}$ \\
\hline
\end{tabular}

Gerek mianserin, gerekse metformin uygulamaları oral (p.o) yoldan yapılmıştır.
Her bir deney grubu 7 adet sıçandan oluşmaktadır.

\section{Açlık kan glukozunun ölçümü}

Hayvanların açlık kan glukoz düzeyleri, 12 saat açliktan sonra kuyruk veninden alınan kandan Glukotrend ${ }^{\circledR}$ cihazı yardımıyla ölçülmüştür.

\section{Oral glukoz tolerans testi (OGTT)}

OGT'T, gece boyunca aç birakılmış sıçanlara uygulanmıştır. Siçanların glukoz yüklemesi yapılmadan önceki (0. dakika) kan glukoz seviyeleri kuyruk venlerinden alınan kandan Glukotrend ${ }^{\circledR}$ cihazı yardımıyla ölçülmüştür. Daha sonra, sıçanlara $2 \mathrm{~g} / \mathrm{kg}$ glukoz solüsyonu oral gavaj ile uygulanmıştır. Glukoz yüklemesinden 30, 60, 90 ve 120 dakika sonra kan glukoz seviyeleri tekrar ölçülerek kaydedilmiştir ${ }^{22}$.

\section{Metabolik kafes ölçümleri}

Kontrol ve deney gruplarındaki hayvanlar deney süresi boyunca metabolik kafeslerde tutulmuş ve aşağıdaki parametreler ölçülmüştür.
a. Günlük su tüketimi
b. Günlük idrar atılımı
c. Günlük yem tüketimi
d. Günlük dışkı miktarları

Metabolik kafes ölçümleri her gün aynı saate yapılmıştır. Sıçanların vücut ağırlığ1 ölçümleri ise deney süresince haftada bir kez yapılmıştır.

\section{Hemoglobin A1c değerlerinin ölçülmesi}

In vivo deney protokolünün tamamlanmasını takiben, diyabetik sıçanlar ketamin ve ksilazin kombinasyonu ile anestezi altına alınmış ve intrakardiyak yolla kan toplanmıştır. HbA1c miktarları, sıçan glikozile HbA1c ELISSA Kit (USB katolog no: CSB-E08140r) yöntemine göre ölçülmüştür. Bu yöntemde kit içerisinde yer alan sıçan HbA1c proteinine özgü bir poliklonal antikor kaplanmış 96'lı plaka kuyucukları kullanılarak deney gruplarına ait HbA1c miktarları kolorometrik yöntemle ölçülmüş̧ür.

Tüm deney grupları aynı anda çalışılmıştır. İnkübasyon süresi sonunda plaka kuyucuklarındaki numunelerin absorbansi $450 \mathrm{~nm}$ dalga boyunda Cytation 3 Cell Imaging Multi-Mode Reader (Biotek) cihazı kullanılarak okunmuştur. Örneklerin HbA1c miktarları, kit içerisinde bulunan ve HbA1c 
miktarları bilinen standart konsantrasyonlar $(0,1.25$, $2.5,5,10,20,40,80 \mathrm{ng} / \mathrm{ml}$ ) ile çizilen standart grafiğge göre, ng/ml olarak hesaplanmıştır ${ }^{23}$.

\section{Siçan pankreas dokusunda INS-1 mRNA ekspresyonlarının gerçek zamanlı polimeraz zincir reaksiyonu yöntemi ile analizi}

Anestezi altındaki sıçanlardan kan alımı ișlemi tamamlandiktan sonra, hayvanların pankreas dokuları hızla çıkartılmışır. Her bir deney grubundaki sıçanlarda insülin ekspresyon miktarını ölçmek için gerçek zamanlı polimeraz zincir reaksiyonu (RT-PCR) metodu kullanılmıştır. Bu yöntemde RNA'dan komplementer deoksiribonükleik asid (cDNA) sentezi ve cDNA'dan da Insulin-1 (Ins-1) (Roche Lot: 90007141) geninin amplifikasyonu yapılarak, Ins-1 geninin mesajc1 ribonükleik asid (mRNA) ekspresyon düzeyleri araştırılmıştır. Housekeeping gen olarak $\beta$-aktin (Actb) (Roche Lot Number: 90006540) kullanılmıştır.

\section{Total ribonükleik asid izolasyonu}

Alınan pankreas doku örneklerinden (0.2 gr) total RNA, izolasyon robotu (MagNA Pure Compact) kullanılarak izole edilmiștir. RNA verimi $260 \mathrm{~nm}$ ve $280 \mathrm{~nm}$ optik dansitede, nanodrop spektrofotometrik ölçüm yapılarak belirlenmiştir. Daha sonra cDNA sentezi için her bir örnekten eşit miktarda RNA (100 ng/örnek), cDNA sentezi için kullanılmıştır.

\section{Komplementer deoksiribonükleik asid sentezi}

cDNA sentezi için Transcriptor High Fidelity cDNA Synthesis kit (katolog no:05091284001, Roche) prosedürü uygulanmıştır. PCR tüplerine örnek başina 100 ng total RNA, $1 \mu$ l Oligo (dT)18 primeri $(2.5 \mu \mathrm{M})$ koyularak toplam hacim $11.4 \mu$ l'ye distile su ile tamamlanmıştır. Tüpler PCR Thermal Cycler'da 10 dakika $65^{\circ} \mathrm{C}$ 'de denature edilmiștir. Tüplerin içeriğine, $4 \mu \mathrm{l}$ Transcriptor High Fidelity Reverse Transcriptase Reaction Buffer (1X ve 8 $\mathrm{mM} \mathrm{MgCl} 2$ içerir), $0.5 \mu \mathrm{l}$ RNase inhibitörü $(20 \mathrm{U}), 2$ $\mu \mathrm{l}$ dNTP karışımı (nükleotid trifosfatlar) (her biri $10 \mathrm{mM}$ ), $1 \mu$ l DTT (dithiothreitol) $(5 \mathrm{mM}), 1.1 \mu \mathrm{l}$ Transcriptor High Fidelity Reverse Transcriptase (10 U) ilave edilerek toplam hacim $20 \quad \mu$ l'ye tamamlanmıştır. Daha sonra tüpler PCR Thermal
Cycler'da $55^{\circ} \mathrm{C}$ 'de $30 \mathrm{dk}, 85{ }^{\circ} \mathrm{C}$ 'de $5 \mathrm{dk}$ inkübe edilmiştir. Elde edilen cDNA'lar, Light Cycler 480 PCR cihazında amplifikasyon için kullanılmıştır.

\section{Gerçek zamanlı polimeraz zincir reaksiyonu yöntemi ile mRNA ekspresyon düzeylerinin belirlenmesi}

Mianserin'in Ins-1 mRNA ekspresyon düzeylerine olan etkileri RT-PCR ile araştırılmıştır. RT-PCR yöntemi, cihaza uygun kit ve primerler kullanilarak uygulanmıștır. Elde edilen cDNA'lar, LightCycler 480 RT-PCR cihazında, TaqMan'lı primerler (Ins-1 ve housekeeping gen olarak da $\beta$-aktin (Actb)) ve PCR kit (Light Cycler 480 Probe Master, Roche Lot Number: 14944920) kullanılarak kit protokolüne göre, cihazda optimize edilerek çoğaltılmıştır. House keeping gen olarak Actb kullanılmıştır.

Light Cycler PCR 480 cihazında 96'lik well plate'lere sirasiyla; $\mathrm{H}_{2} \mathrm{O}(4 \mu \mathrm{l})$, Prob Master $(10 \mu \mathrm{l})$, Primer (1 $\mu l)$ ve cDNA $(5 \mu l)$ kimyasalları yüklenmiştir. Hazırlanan bu karışım 96'lık plakaya Ins-1 ve Actb için ayrı ayrı yüklenmiștir. Yükleme ișleminden sonra 96'llk plaka LightCycler 480 RT-PCR cihazına yerleştirilip örneklerin niceliksel ölçüm miktarları belirlenmiştir. Sonuçlar 'Advenced Relative Quantification' programı (Software Release 1.5.0 SP4 version 1.5.0.39) kullanılarak, herbir grubun Ins-1 mRNA ekspresyonun eşik değerleri (crossing point, CP) analiz edilmiş ve grupların Ins-1 geni mRNA ekspresyon düzeyleri karşılaştırılmıştır.

\section{İstatistiksel analiz}

İstatistiksel analizler için Graphpad Prism paket programı kullanılmıştır. Değişkenlerin normal dağılıma uygunluğu Shapiro-Wilk testi kullanılarak incelenmiştir. Serum fizyolojik, $30 \mathrm{mg} / \mathrm{kg}$ mianserin ve $45 \mathrm{mg} / \mathrm{kg}$ mianserin uygulanan normoglisemik sıçan gruplarına ait olan ve haftalar arasında karşılaştırma yapmayı gerektiren veriler, çift yönlü varyans analizi (ANOVA)-tekrarlı ölçüm testi ve ardından Bonferroni çoklu karşılaştırma testi uygulanarak değerlendirilmiştir. Serum fizyolojik uygulanan normoglisemik ve serum fizyolojik, referans madde (metformin), $30 \mathrm{mg} / \mathrm{kg}$ mianserin ve $45 \mathrm{mg} / \mathrm{kg}$ mianserin uygulanan diyabetik siçan gruplarına ait olan ve haftalar arasında karşılaştırma yapmayı gerektiren veriler, çift yönlü varyans analizi (ANOVA)-tekrarlı ölçüm testi ve ardından Bonferroni çoklu karşılaştırma testi uygulanarak değerlendirilmiştir. HbA1c miktarlarına ilişkin veriler 
ise tek yönlü varyans analizini takiben Tukey çoklu karşılaştırma testi uygulanarak değerlendirilmiştir. Sonuçlar, ortalamatortalamanın standart hatası olarak verilmiştir. $\mathrm{P}<0,05$ değeri anlamlı kabul edilmiştir. Grafik çizimleri için Microsoft Office Excell programlarından yararlanılmıştır.

\section{BULGULAR}

\section{Açlık kan glukoz değerlerine ilişkin bulgular}

7 ve 14 gün boyunca her gün düzenli olarak 30 ve 45 $\mathrm{mg} / \mathrm{kg}$ mianserin uygulanan normoglisemik sıçanların açlık kan glukoz değerleri, serum fizyolojik uygulanan normoglisemik sıçanların açlık kan glukoz değerlerinden farklı bulunmamıştır. Çift yönlü tekrarlı varyans analizi sonuçları sıçanların açlık kan glukoz değerleri üzerinde ne tedavi faktörünün [F $(6,54)=0.98, P>0.05]$ ne de zaman faktörünün $[\mathrm{F}$ $(6,54)=0.33, \quad \mathrm{P}>0.05] \quad$ etkili olmadiğını ortaya koymuştur. Ayrica, tedavi ile zaman arasında anlamlı bir etkileşim de bulunmamaktadır $[\mathrm{F}(6,54)=0.51$, $\mathrm{P}>0.05$ ] (Tablo 1).

Şekil 1, 14 gün boyunca her gün düzenli olarak serum fizyolojik uygulanan normoglisemik (kontrol) ve serum fizyolojik, $1 \mathrm{~g} / \mathrm{kg}$ metformin, $30 \mathrm{mg} / \mathrm{kg}$ mianserin ve $45 \mathrm{mg} / \mathrm{kg}$ mianserin uygulanan diyabetik sıçanların açlık kan glukoz değerlerinin değişimini göstermektedir. Çift yönlü tekrarlı varyans analizi sonuçları sıçanların açlık kan glukoz değerleri üzerinde hem tedavi faktörünün $[\mathrm{F}$ $(12,90)=105.2, \mathrm{P}<0.001]$ hem de zaman faktörünün $[\mathrm{F}(12,90)=272.4, \mathrm{P}<0.001]$ etkili olduğunu ortaya koymaktadır. Ayrica, tedavi ile zaman arasinda anlamlı bir etkileşim bulunmaktadır $[\mathrm{F}$ $(12,90)=22.88, \mathrm{P}<0.001]$.

Çoklu karşılaştırma için uygulanan Bonferroni testi, diyabet (DM), $1 \mathrm{~g} / \mathrm{kg}$ metformin uygulanmış diyabet (Metformin+DM), $30 \mathrm{mg} / \mathrm{kg}$ mianserin uygulanmış diyabet (MNS-30+DM) ve $45 \mathrm{mg} / \mathrm{kg}$ mianserin uygulanmış diyabet (MNS-45+DM) gruplarında bulunan hayvanların STZ uygulamasını izleyen 4. haftada ölçülen kan glukoz değerlerinin, 0. hafta değerlerine göre anlamlı biçimde arttığını göstermiştir. Bonferroni testi, referans madde olarak kullanılan metformin'in (1 $\mathrm{g} / \mathrm{kg}) \quad 7$ ve 14 gün subakut uygulamasının diyabetik sıçanların artmış kan glukoz seviyelerini anlamlı biçimde azalttığını ortaya koymuştur. Metformin'in yanı sıra mianserin'in 30 ve $45 \mathrm{mg} / \mathrm{kg}$ dozlarının 7 ve 14 günlük subakut uygulamaları da diyabetik sıçanların artmış kan glukoz seviyelerini istatistiksel olarak anlamlı biçimde azaltmıştır (Şekil 1).

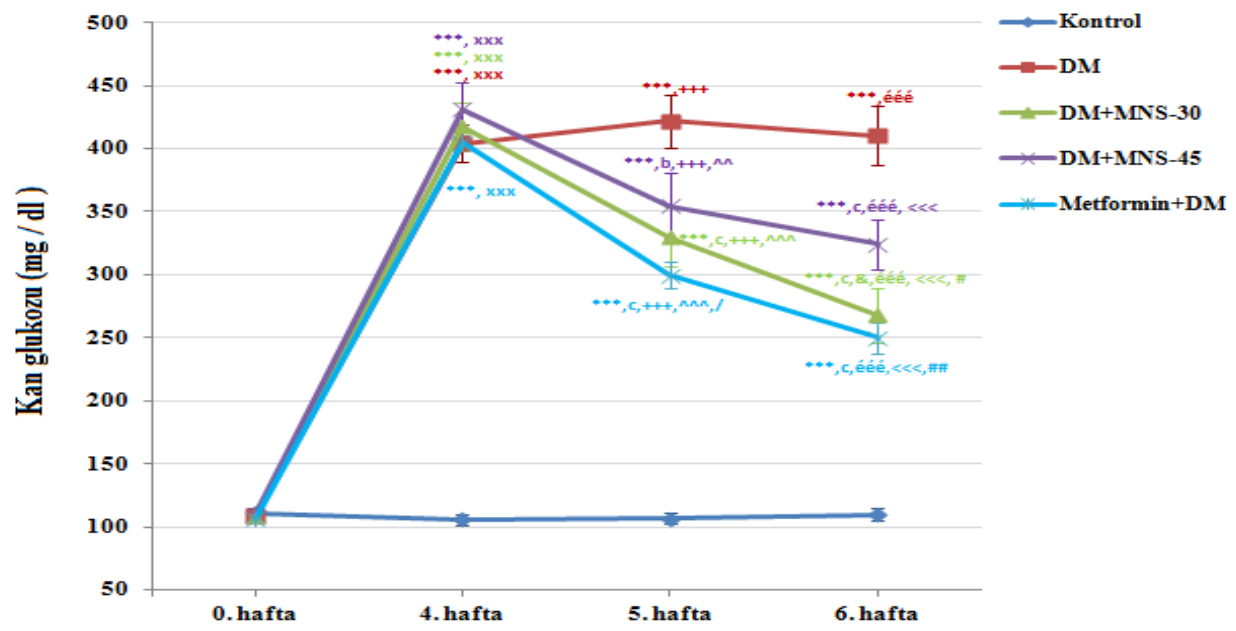

Şekil 1. Serum fizyolojik uygulanan normoglisemik (Kontrol) ve serum fizyolojik (DM), $1 \mathrm{~g} / \mathrm{kg}$ metformin (Metformin+DM), $30 \mathrm{mg} / \mathrm{kg}$ mianserin (MNS-30+DM) ve $45 \mathrm{mg} / \mathrm{kg}$ mianserin (MNS-45+DM) uygulanan diyabetik sıçanların açlık kan glukoz değerleri

0 . haftaya göre anlamlı farklılık ${ }^{* * *} \mathrm{p}<0.001 ; 4$. haftaya göre anlamlı farklılık ${ }^{\mathrm{b}} \mathrm{p}<0.01,{ }_{\mathrm{p}}^{\mathrm{c}}<0.001 ; 5$. haftaya göre anlamlı farklıllk ${ }_{\mathrm{p}} \mathrm{p}<0.05 ; 4$. hafta kontrol grubuna göre anlamlı farkl1l1k ${ }^{\mathrm{xxx}} \mathrm{p}<0.001 ; 5$. hafta kontrol grubuna göre anlamlı farkl1l1k ${ }^{+++} \mathrm{p}<0.001 ; 6$. hafta kontrol grubuna göre anlamlı farklılık éée $\mathrm{p}<0.001$; 5. hafta DM grubuna göre anlamlı farklılık ^^p<0.01, ^^p $<0.001 ; 6$. hafta DM grubuna göre anlamlı farklılık $\ll<\mathrm{p}<0.001 ; 5$. hafta MNS-45 grubuna göre anlamlı farklılık / $<<0.05 ; 6$. hafta MNS-45 grubuna göre anlamlı farklılık ${ }^{\#} \mathrm{p}<0.05,{ }^{\# \#} \mathrm{p}<0.01$, Çift yönlü tekrarlı varyans analizi, takiben Bonferroni çoklu karşılaştırma testi, $\mathrm{n}=7$. 
Tablo 1. Serum fizyolojik (kontrol), $30 \mathrm{mg} / \mathrm{kg}$ mianserin (MNS-30) ve $45 \mathrm{mg} / \mathrm{kg}$ mianserin (MNS-45) uygulanan normoglisemik sıçanların kan glukozlarındaki $(\mathrm{mg} / \mathrm{dl})$, metabolik parametrelerindeki ve vücut ağırlıklarındaki değişime ilişkin değerler.

\begin{tabular}{|c|c|c|c|c|c|c|}
\hline & & $\begin{array}{l}\text { Tedavi } \\
\text { öncesi } \\
\text { (0. hafta) }\end{array}$ & $\begin{array}{l}\text { Tedavi öncesi } \\
\text { (4. hafta) }\end{array}$ & & $\begin{array}{l}\text { tedavili } \\
\text { fta) }\end{array}$ & $\begin{array}{l}14 \text { gün tedavili } \\
\text { (6. hafta) }\end{array}$ \\
\hline \multirow{5}{*}{$\begin{array}{l}\text { Kan } \\
\text { glukozu } \\
(\mathrm{mg} / \mathrm{dl})\end{array}$} & Kontrol & $124.1 \pm 4.1$ & \multicolumn{2}{|l|}{$122.7 \pm 5.5$} & $123.3 \pm 4.4$ & $124.4 \pm 4.9$ \\
\hline & MNS-30 & $120.0 \pm 4.9$ & \multicolumn{2}{|l|}{$119.1 \pm 4.5$} & $118.1 \pm 5.6$ & $117.6 \pm 5.6$ \\
\hline & MNS-45 & $112.9 \pm 6.6$ & \multicolumn{2}{|l|}{$114.6 \pm 5.9$} & $113.0 \pm 5.8$ & $112.0 \pm 7.1$ \\
\hline & & \multicolumn{5}{|c|}{ Zaman (dak) } \\
\hline & & 0 & \multicolumn{2}{|l|}{30} & 90 & 120 \\
\hline \multirow{3}{*}{$\begin{array}{l}\text { Kan } \\
\text { glukozu, } \\
\text { (OGTT) } \\
(\mathrm{mg} / \mathrm{dl})\end{array}$} & Kontrol & $124,4 \pm 4.9$ & $160.6 \pm 11.1$ & $189.4 \pm 6.1$ & $173.0 \pm 10.5$ & $151.7 \pm 6.3$ \\
\hline & MNS-30 & $117.6 \pm 5.6$ & $149.9 \pm 6.3$ & $179.6 \pm 4.7$ & $168.0 \pm 5.6$ & $146.1 \pm 2.8$ \\
\hline & MNS-45 & $112.0 \pm 7.1$ & $145.6 \pm 11.1$ & $168.4 \pm 8.1$ & $161.7 \pm 4.8$ & $137.3 \pm 6.4$ \\
\hline \multirow{3}{*}{$\begin{array}{l}\text { Tüketilen } \\
\text { su hacmi } \\
\text { (ml) }\end{array}$} & Kontrol & $35.2 \pm 2.9$ & \multicolumn{2}{|l|}{$39.3 \pm 3.0$} & $37.5 \pm 3.5$ & $36.3 \pm 2.5$ \\
\hline & MNS-30 & $34.2 \pm 2.4$ & \multirow{2}{*}{\multicolumn{2}{|c|}{$\begin{array}{l}37.3 \pm 3.2 \\
35.3+1.3\end{array}$}} & $36.3 \pm 3.3$ & $38.3 \pm 2.9$ \\
\hline & MNS-45 & $32.5 \pm 3.0$ & & & $33.8 \pm 2.7$ & $36.1 \pm 3.0$ \\
\hline \multirow{3}{*}{$\begin{array}{l}\text { Attlan } \\
\text { idrar } \\
\text { hacmi } \\
\text { (ml) }\end{array}$} & Kontrol & $12.8 \pm 1.5$ & \multicolumn{2}{|l|}{$14.2 \pm 1.2$} & $14.0 \pm 0.9$ & $13.5 \pm 1.2$ \\
\hline & MNS-30 & $13.1 \pm 0.8$ & \multicolumn{2}{|l|}{$13.71 \pm 1.5$} & $13.50 \pm 1.1$ & $14.0 \pm 1.1$ \\
\hline & MNS-45 & $12.3 \pm 1.0$ & \multicolumn{2}{|l|}{$13.9 \pm 1.3$} & $12.8 \pm 1.0$ & $13.9 \pm 1.2$ \\
\hline \multirow{3}{*}{$\begin{array}{l}\text { Tüketilen } \\
\text { yem } \\
\text { miktarı } \\
\text { (g) }\end{array}$} & Kontrol & $19.6 \pm 1.2$ & \multicolumn{2}{|l|}{$18.6 \pm 1.4$} & 1.8 & $18.8 \pm 1.1$ \\
\hline & MNS-30 & $19.1 \pm 1.6$ & $18.0 \pm 1.5$ & & 1.7 & $18.1 \pm 1.8$ \\
\hline & MNS-45 & $18.5 \pm 1.4$ & $19.4 \pm 1.5$ & & 1.3 & $17.2 \pm 0.8$ \\
\hline Atılan & Kontrol & $14.7 \pm 1.4$ & $13.8 \pm 1.3$ & & 1.1 & $14.1 \pm 1.1$ \\
\hline dişkı & MNS-30 & $14.1 \pm 0.9$ & $13.6 \pm 1.2$ & & 1.3 & $13.9 \pm 1.3$ \\
\hline $\begin{array}{l}\text { miktar1 } \\
(\mathrm{g})\end{array}$ & MNS-45 & $13.1 \pm 1.5$ & $14.0 \pm 1.6$ & & 1.4 & $12.5 \pm 1.0$ \\
\hline Vücut & Kontrol & $265.6 \pm 11.8$ & $273.3 \pm 9.3$ & & \pm 8.9 & $298.7 \pm 10.9^{*}$ \\
\hline ağırlı̆̆g & MNS-30 & $272.9 \pm 7.2$ & $279.0 \pm 10.1$ & & \pm 7.9 & $293.1 \pm 8.9$ \\
\hline (g) & MNS-45 & $268.0 \pm 9.1$ & $274.3 \pm 7.9$ & & \pm 11.2 & $296.4 \pm 17.9$ \\
\hline
\end{tabular}

\section{Oral glukoz tolerans testine ilişkin bulgular}

7 ve 14 gün boyunca her gün düzenli olarak 30 ve 45 $\mathrm{mg} / \mathrm{kg}$ mianserin uygulanan normoglisemik siçanların $2 \mathrm{~g} / \mathrm{kg}$ glukoz yüklemesinden sonra 30 , 60., 90. ve 120. dakikalarda ölçülen kan glukoz değerleri, kontrol grubu normoglisemik sıçanların glukoz yüklemesinden sonra ölçülen kan glukoz değerlerinden farklı bulunmamıştır. Çift yönlü tekrarlı varyans analizi sonuçları sıçanların OGTT'de ölçülen kan glukoz değerleri üzerine tedavi faktörünün $[\mathrm{F} \quad(8,72)=2.34, \quad \mathrm{P}>0.05] \quad$ etkili olmadığını ortaya koymaktadır. Diğer yandan, süre faktörünün kan glukozu üzerinde anlamlı etki gösterdiği belirlenmiştir $[\mathrm{F}(8,72)=47.12, \mathrm{P}<0.001]$. Tedavi ile zaman faktörleri arasinda anlamlı bir etkileşim bulunmamaktadır $[\mathrm{F}(8,72)=0.14, \mathrm{P}>0.05]$ (Tablo 1).

Şekil 2, 14 gün boyunca her gün düzenli olarak serum fizyolojik uygulanan normoglisemik (kontrol) ve serum fizyolojik, $1 \mathrm{~g} / \mathrm{kg}$ metformin, $30 \mathrm{mg} / \mathrm{kg}$ mianserin ve $45 \mathrm{mg} / \mathrm{kg}$ mianserin uygulanan diyabetik sıçanların OGTT sonrası ölçülen kan glukoz değerlerini göstermektedir. Çift yönlü tekrarlı varyans analizi sonuçları sıçanların glukoz yüklemesini takiben ölçülen kan glukoz değerleri üzerinde hem tedavi faktörünün $[\mathrm{F}(16,120)=84.94$, $\mathrm{P}<0.001]$ hem de süre faktörünün $[\mathrm{F}$ $(16,120)=142.10, \quad \mathrm{P}<0.001]$ etkili olduğunu ortaya koymaktadır. Ayrıca, tedavi ile zaman arasında anlamlı bir etkileşim bulunmaktadır [F $(16,120)=11 \cdot 37, \quad P<0.001]$. Çoklu karşılaştırma için uygulanan Bonferroni testi, DM grubunda bulunan sıçanların OGT'T'yi takiben 0., 30., 60., 90. ve 120. dakikalarda ölçülen kan glukoz değerlerinin karşılık gelen normoglisemik kontrol grubu değerlerinden anlamlı biçimde yüksek olduğunu göstermiştir. 1 $\mathrm{g} / \mathrm{kg}$ metformin, $30 \mathrm{mg} / \mathrm{kg}$ mianserin ve $45 \mathrm{mg} / \mathrm{kg}$ 
mianserin tedavisi almış olan diyabetik hayvanların OGTT'yi takiben ölçülen kan glukoz değerleri ise, serum fizyolojik uygulanan DM grubunun karşıllk gelen değerlerinden anlamlı biçimde düşüktür (Şekil 2).

\section{Metabolik kafes ölçümlerine ilişkin bulgular}

\section{Su tüketimine ilişkin bulgular}

7 ve 14 gün boyunca her gün düzenli olarak 30 ve 45 $\mathrm{mg} / \mathrm{kg}$ mianserin uygulanan normoglisemik siçanların su tüketim değerleri, serum fizyolojik uygulanan normoglisemik sıçanların su tüketim değerlerinden farklı bulunmamıştır. Çift yönlü tekrarlı varyans analizi sonuçları sıçanların su tüketim değerleri üzerinde ne tedavi faktörünün $[\mathrm{F}$ $(6,54)=0.32, P>0.05]$ ne de zaman faktörünün $[\mathrm{F}$
$(6,54)=2.70, \quad \mathrm{P}>0.05] \quad$ etkili olmadığını ortaya koymuştur. Ayrıca, tedavi ile zaman arasında anlamlı bir etkileşim de bulunmamaktadır $[\mathrm{F}(6,54)=0.41$, $\mathrm{P}>0.05]$ (Tablo 1).

Şekil 3, 14 gün boyunca her gün düzenli olarak serum fizyolojik uygulanan normoglisemik (kontrol) ve serum fizyolojik, $1 \mathrm{~g} / \mathrm{kg}$ metformin, $30 \mathrm{mg} / \mathrm{kg}$ mianserin ve $45 \mathrm{mg} / \mathrm{kg}$ mianserin uygulanan diyabetik sıçanların su tüketim değerlerini göstermektedir. Çift yönlü tekrarlı varyans analizi sonuçları sıçanların su tüketim değerleri üzerinde hem tedavi faktörünün $[\mathrm{F}(12,90)=24.86, \mathrm{P}<0.001]$ hem de zaman faktörünün $[F \quad(12,90)=322.8$, $\mathrm{P}<0.001]$ etkili olduğunu ortaya koymaktadır. Ayrica, tedavi ile zaman arasinda anlamlı bir etkileşim bulunmaktadır $[\mathrm{F}(12,90)=38.04, \mathrm{P}<0.001]$.

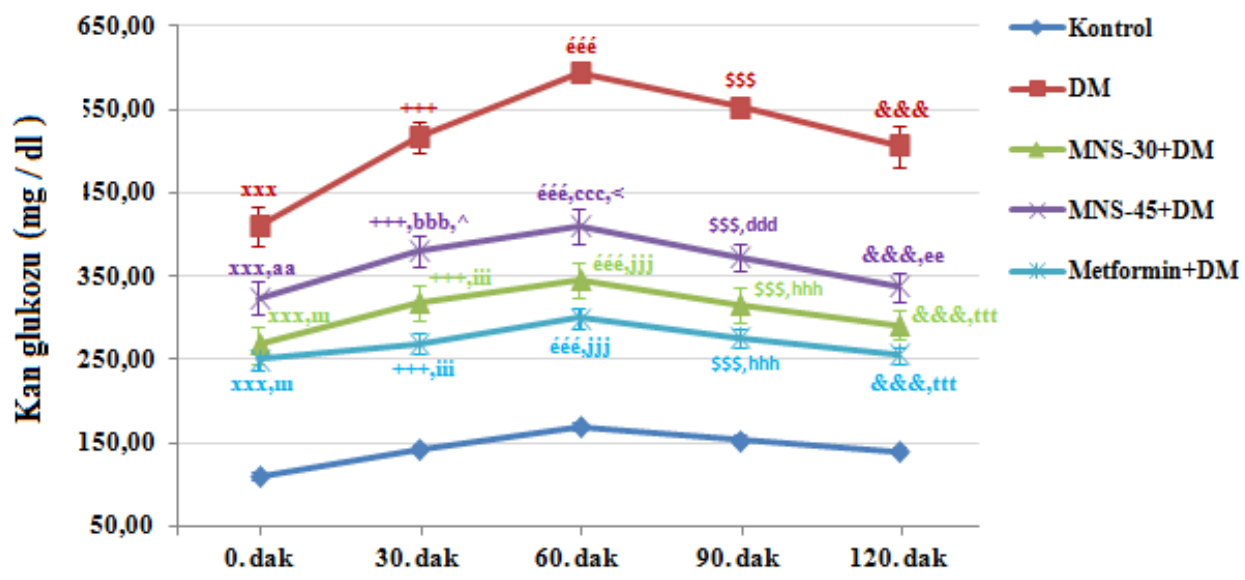

Şekil 2. 14 günlük uygulamaların bitiminde, serum fizyolojik uygulanan normoglisemik (Kontrol) ve serum fizyolojik (DM), $1 \mathrm{~g} / \mathrm{kg}$ metformin (Metformin+DM), $30 \mathrm{mg} / \mathrm{kg}$ mianserin (MNS-30+DM) ve $45 \mathrm{mg} / \mathrm{kg}$ mianserin (MNS45+DM) uygulanan diyabetik sıçanların OGTT'de ölçülen kan glukoz değerleri,

0. dakika kontrol grubuna göre anlamlı farklılık xxx $p<0.001$; 30. dakika kontrol grubuna göre anlamlı farklılık ${ }^{+++} p<0.001 ; 60$. dakika kontrol grubuna göre anlamlı farklılık éé $p<0.001$, 90. dakika kontrol grubuna göre anlamlı farklılık $\$ \$ p<0.001,120$. dakika kontrol grubuna göre anlamlı farklllı \&\&\& $p<0.001 ; 0$. dakika DM grubuna göre anlaml farklllık "'p<0.001; 30. dakika DM grubuna göre anlamlı farklılık iiii $p<0.001$; 60. dakika DM grubuna göre anlamlı farklılık iii $p<0.001$, 90. dakika DM grubuna göre anlamlı farklılık hhh $p<0.001,120$. dakika DM grubuna göre anlamlı farkll11k ttt $p<0.001 ; 0$. Dakika Metformin+DM grubuna göre anlamlı farklllı aa $p<0.01 ; 30$. Dakika Metformin+DM grubuna göre anlamlı farklılık bbb $p<0.001 ; 60$. dakika Metformin+DM grubuna göre anlamlı farklılık ccc $p<0.001,90$. dakika Metformin+DM grubuna göre anlamlı farklılık ddd $p<0.001$, 120. dakika Metformin+DM grubuna göre anlamlı farklılık ee $p<0.01$; 30. dakika MNS-30+DM grubuna göre anlamlı farklılık ${ }^{p} p<0.05$; 60. Dakika MNS-30+DM grubuna göre anlamlı farklılık $<p<0.05$, Çift yönlü tekrarlı varyans analizi, takiben Bonferroni çoklu karşılaştırma testi, $n=7$.

Çoklu karşılaştırma için uygulanan Bonferroni testi, diyabet (DM), $1 \mathrm{~g} / \mathrm{kg}$ metformin uygulanmış diyabet (Metformin+DM), $30 \mathrm{mg} / \mathrm{kg}$ mianserin uygulanmıs diyabet (MNS-30+DM) ve $45 \mathrm{mg} / \mathrm{kg}$ mianserin uygulanmış diyabet (MNS-45+DM) gruplarında bulunan hayvanların STZ uygulamasını izleyen 4. haftada ölçülen su tüketim değerlerinin, 0 . hafta değerlerine göre anlamlı biçimde arttığını göstermiştir. Diyabetik hayvanlarda artmış olan su tüketim değerleri referans madde olarak kullanılan 
metformin'in (1 $\mathrm{g} / \mathrm{kg}) 7$ ve 14 günlük subakut uygulamaları ile anlamlı ölçüde azalmışır. Metformin'in yanı sira mianserin'in 30 ve $45 \mathrm{mg} / \mathrm{kg}$ dozlarının 7 ve 14 gün subakut uygulamaları da diyabetik sıçanların artmış su tüketim değerlerini istatistiksel olarak anlamlı ölçüde azaltmıştır (Şekil 3).

\section{İdrar atılımına ilişkin bulgular}

7 ve 14 gün boyunca her gün düzenli olarak 30 ve 45 $\mathrm{mg} / \mathrm{kg}$ mianserin uygulanan normoglisemik sıçanların idrar atılım değerleri, serum fizyolojik uygulanan normoglisemik sıçanların idrar atılım değerlerinden farklı bulunmamıştır. Çift yönlü tekrarlı varyans analizi sonuçları sıçanların idrar atılım değerleri üzerinde ne tedavi faktörünün $[\mathrm{F}$
$(6,54)=0.05, \mathrm{P}>0.05]$ ne de zaman faktörünün $[\mathrm{F}$ $(6,54)=2.55, \quad \mathrm{P}>0.05]$ etkili olmadiğını ortaya koymuştur. Ayrıca, tedavi ile zaman arasında anlamlı bir etkileşim de bulunmamaktadır $[\mathrm{F}(6,54)=0.47$, $\mathrm{P}>0.05$ ] (Tablo 1).Şekil 4. 14 gün boyunca her gün düzenli olarak serum fizyolojik uygulanan normoglisemik (kontrol) ve serum fizyolojik, $1 \mathrm{~g} / \mathrm{kg}$ metformin, $30 \mathrm{mg} / \mathrm{kg}$ mianserin ve $45 \mathrm{mg} / \mathrm{kg}$ mianserin uygulanan diyabetik sıçanların idrar atılım değerlerini göstermektedir. Çift yönlü tekrarlı varyans analizi sonuçları sıçanların idrar atılım değerleri üzerinde hem tedavi faktörünün $[\mathrm{F}$ $(12,90)=30.33, \mathrm{P}<0.001]$ hem de zaman faktörünün $[\mathrm{F}(12,90)=263.7, \mathrm{P}<0.001]$ etkili olduğunu ortaya koymaktadır. Ayrica, tedavi ile zaman arasinda anlamlı bir etkileşim bulunmaktadır $[\mathrm{F}(12,90)=30.6$, $\mathrm{P}<0.001]$.

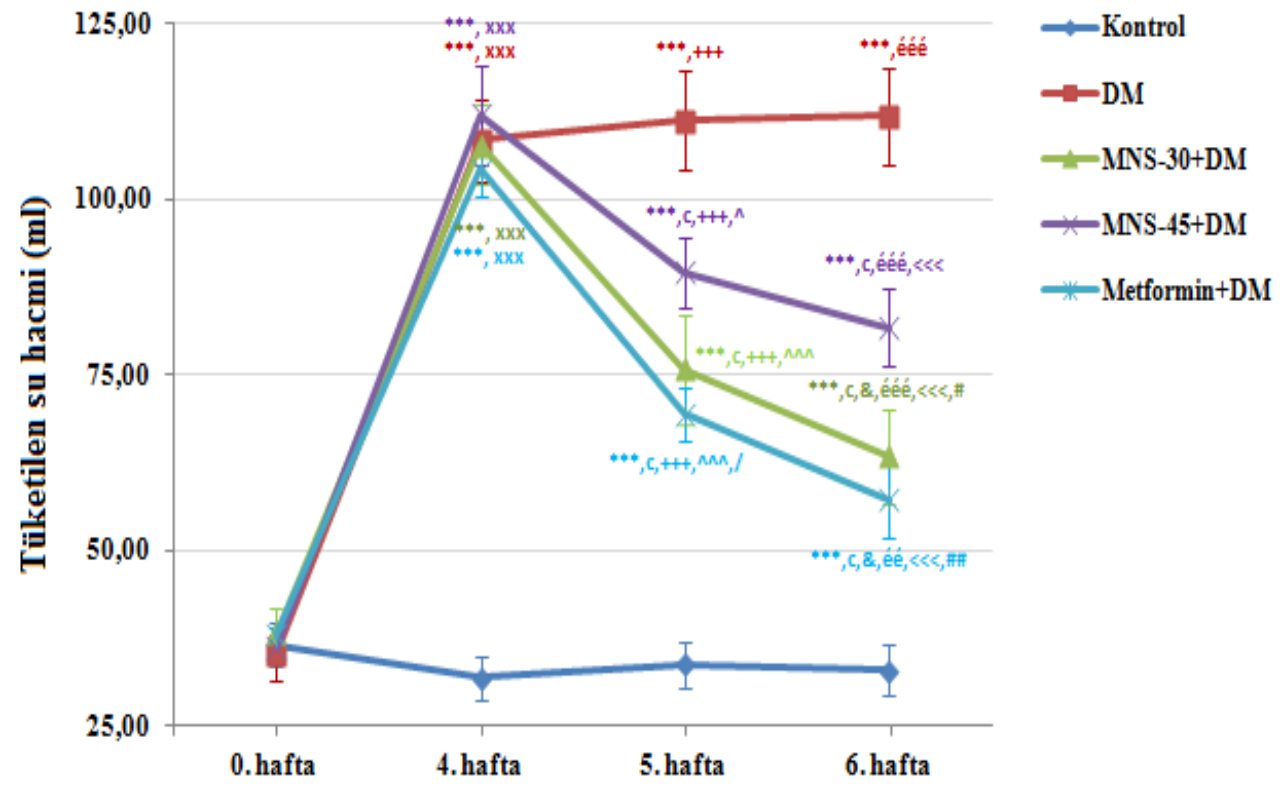

Şekil 3. Serum fizyolojik uygulanan normoglisemik (Kontrol) ve serum fizyolojik (DM), $1 \mathrm{~g} / \mathrm{kg}$ metformin (Metformin+DM), $30 \mathrm{mg} / \mathrm{kg}$ mianserin (MNS-30+DM) ve $45 \mathrm{mg} / \mathrm{kg}$ mianserin (MNS-45+DM) uygulanan diyabetik sıçanların su tüketim değerleri,

0. haftaya göre anlamlı farklılık ${ }^{* * *} p<0.001 ; 4$. haftaya göre anlamlı farklılık ${ }^{c} p<0.001 ; 5$. haftaya göre anlamlı farklılık \& $p<0.05 ; 4$. hafta kontrol grubuna göre anlamlı farklılık ${ }^{\mathrm{xxx}} p<0.001 ; 5$. hafta kontrol grubuna göre anlamlı farkll11k ${ }^{+++} p<0.001 ; 6$. hafta kontrol grubuna göre anlamlı farklılık éé $p<0.01$, éé $p<0.001 ; 5$. hafta DM grubuna göre anlamlı farklılık $p<0.05,{ }^{\wedge} p<0.001 ; 6$. hafta DM grubuna göre anlamlı farklılık $\ll<p<0.001,5$. hafta MNS-45 grubuna göre anlamlı farklılık / $p<0.05$; 6 . hafta MNS-45 grubuna göre anlamlı farklılık ${ }^{\#} p<0.05,{ }^{\# \#} p<0.01$, Çift yönlü tekrarlı varyans analizi, takiben Bonferroni çoklu karşıllaştırma testi, $\mathrm{n}=7$.

Çoklu karşılaştırma için uygulanan Bonferroni testi, diyabet (DM), $1 \mathrm{~g} / \mathrm{kg}$ metformin uygulanmıs diyabet (Metformin+DM), $30 \mathrm{mg} / \mathrm{kg}$ mianserin uygulanmış diyabet (MNS-30+DM) ve $45 \mathrm{mg} / \mathrm{kg}$ mianserin uygulanmış diyabet (MNS-45+DM) gruplarında bulunan hayvanların STZ uygulamasını izleyen 4. haftada ölçülen idrar atılım değerlerinin, 0. hafta değerlerine göre anlamlı biçimde arttı̆̆ını göstermiştir. Diyabetik hayvanlarda artmış olan idrar atılım değerleri, referans madde olarak kullanılan 
metformin'in (1 $\mathrm{g} / \mathrm{kg}) 7$ ve 14 günlük subakut uygulamaları ile anlamlı ölçüde düzelmiştir. Metformin'in yanı sira mianserin'in 30 ve $45 \mathrm{mg} / \mathrm{kg}$ dozlarının 7 ve 14 günlük subakut uygulamaları da diyabetik sıçanların artmış idrar atılım değerlerini istatistiksel olarak anlamlı ölçüde azaltmıştır (Şekil 4).

\section{Yem tüketimine ilişkin bulgular}

7 ve 14 gün boyunca her gün düzenli olarak 30 ve 45 $\mathrm{mg} / \mathrm{kg}$ mianserin uygulanan normoglisemik sıçanların yem tüketim değerleri, serum fizyolojik uygulanan normoglisemik sıçanların yem tüketim değerlerinden farklı bulunmamıştır. Çift yönlü tekrarlı varyans analizi sonuçları sıçanların yem tüketim değerleri üzerinde ne tedavi faktörünün $[\mathrm{F}$
$(6,54)=0.30, \mathrm{P}>0.05]$ ne de zaman faktörünün $[\mathrm{F}$ $(6,54)=1.63, \quad \mathrm{P}>0.05] \quad$ etkili olmadığını ortaya koymuştur. Ayrıca, tedavi ile zaman arasında anlamlı bir etkileşim de bulunmamaktadır $[\mathrm{F}(6,54)=1.52$, $\mathrm{P}>0.05$ ] (Tablo 1). Şekil 5, 14 gün boyunca her gün düzenli olarak serum fizyolojik uygulanan normoglisemik (kontrol) ve serum fizyolojik, $1 \mathrm{~g} / \mathrm{kg}$ metformin, $30 \mathrm{mg} / \mathrm{kg}$ mianserin ve $45 \mathrm{mg} / \mathrm{kg}$ mianserin uygulanan diyabetik siçanların yem tüketim değerlerini göstermektedir. Çift yönlü tekrarlı varyans analizi sonuçları sıçanların yem tüketim değerleri üzerinde hem tedavi faktörünün [F $(12,90)=30.17, \mathrm{P}<0.001]$ hem de zaman faktörünün $[\mathrm{F}(12,90)=92.43, \mathrm{P}<0.001]$ etkili olduğunu ortaya koymaktadır. Ayrıca, tedavi ile zaman arasinda anlamlı bir etkileşim bulunmaktadır $[\mathrm{F}$ $(12,90)=10.89, \mathrm{P}<0.001]$.

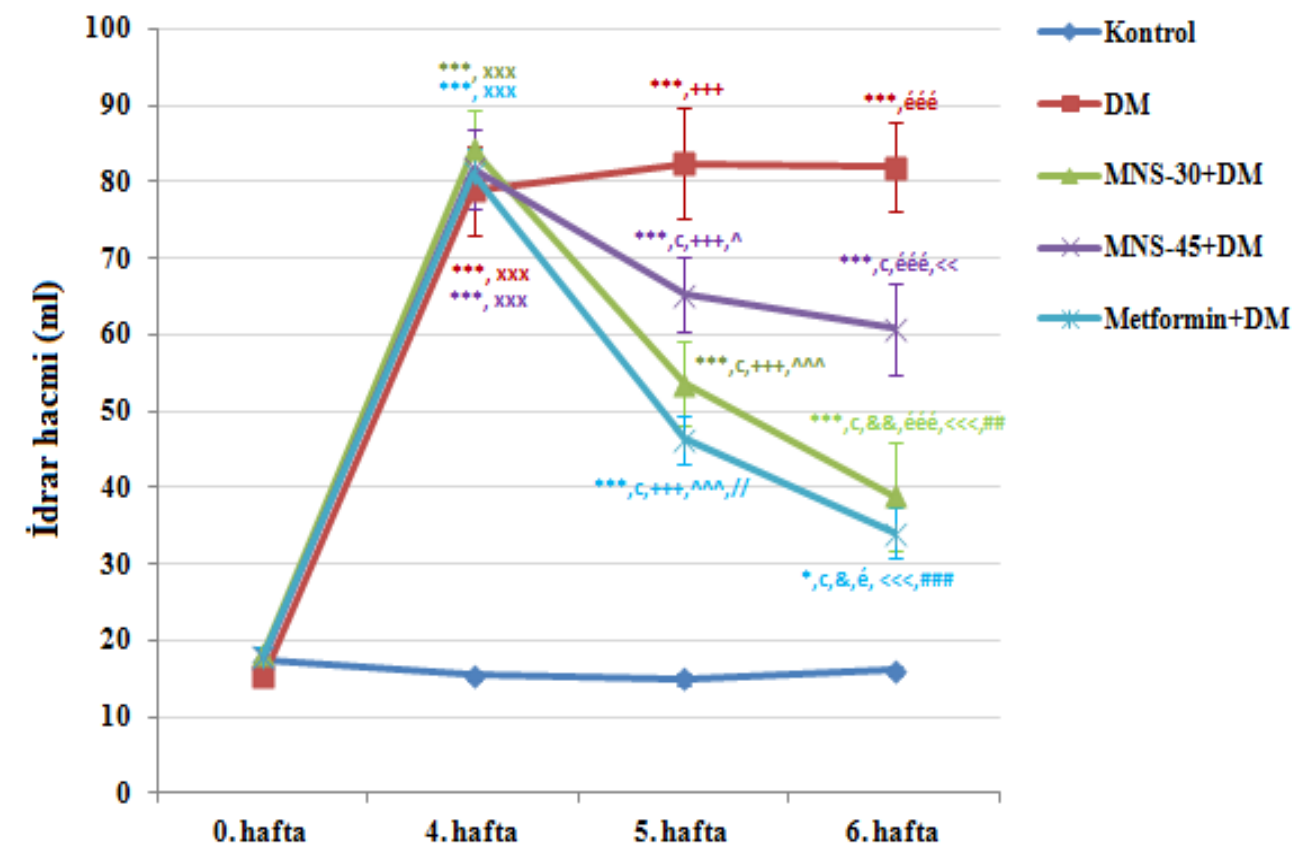

Şekil 4. Serum fizyolojik uygulanan normoglisemik (Kontrol) ve serum fizyolojik (DM), $1 \mathrm{~g} / \mathrm{kg}$ metformin (Metformin+DM), $30 \mathrm{mg} / \mathrm{kg}$ mianserin (MNS-30+DM) ve $45 \mathrm{mg} / \mathrm{kg}$ mianserin (MNS-45+DM) uygulanan diyabetik sıçanların idrar atılım değerleri,

0 . haftaya göre anlaml farklılık ${ }^{*} p<0.05,{ }^{* * *} p<0.001 ; 4$. haftaya göre anlamlı farklılık ${ }^{c} p<0.001 ; 5$. haftaya göre anlaml farklılık $\& p<0.05$, $\& \& p<0.01 ; 4$. hafta kontrol grubuna göre anlamlı farkl1l1k $\operatorname{xxx} p<0.001 ; 5$. hafta kontrol grubuna göre anlamlı farkl1lik ${ }^{+++} p<0.001 ; 6$. hafta kontrol grubuna göre anlamlı farklılık é $p<0.05$, éée $p<0.001 ; 5$. hafta DM grubuna göre anlamlı farklılık ${ }^{\wedge} p<0.05,{ }^{\wedge \wedge} p<0.001 ; 6$. hafta DM grubuna göre anlamlı farklllı $<<p<0.01,<<p<0.001$; 5. hafta MNS-45 grubuna göre anlamlı farklilik // $p<0.01$; 6. hafta MNS-45 grubuna göre anlamlı farklılık \#\# $p<0.01, \# \# p<0.001$, Çift yönlü tekrarlı varyans analizi, takiben Bonferroni çoklu karşılaştırma testi, $\mathrm{n}=7$.

Çoklu karşılaştırma için uygulanan Bonferroni testi diyabet (DM), $1 \mathrm{~g} / \mathrm{kg}$ metformin uygulanmış diyabet
(Metformin+DM), $30 \mathrm{mg} / \mathrm{kg}$ mianserin uygulanmış diyabet (MNS-30+DM) ve $45 \mathrm{mg} / \mathrm{kg}$ mianserin 
uygulanmış diyabet (MNS-45+DM) gruplarında bulunan hayvanların STZ uygulamasinı izleyen 4. haftada ölçülen yem tüketim değerlerinin, 0. hafta değerlerine göre anlamlı biçimde arttığını göstermiştir.

Diyabetik sıçanların yem tüketiminde ortaya çıkan söz konusu artış, referans madde olarak kullanılan metformin'in (1 g/kg) 7 ve 14 günlük subakut uygulamaları ile anlamlı ölçüde azalmıştır. Metformin'in yanı sira mianserin'in 30 ve $45 \mathrm{mg} / \mathrm{kg}$ dozlarının 7 ve 14 günlük subakut uygulamaları da diyabetik sıçanların 4 . haftadaki yüksek yem tüketim değerlerini istatistiksel olarak anlamlı ölçüde azaltmıştır (Şekil 5).

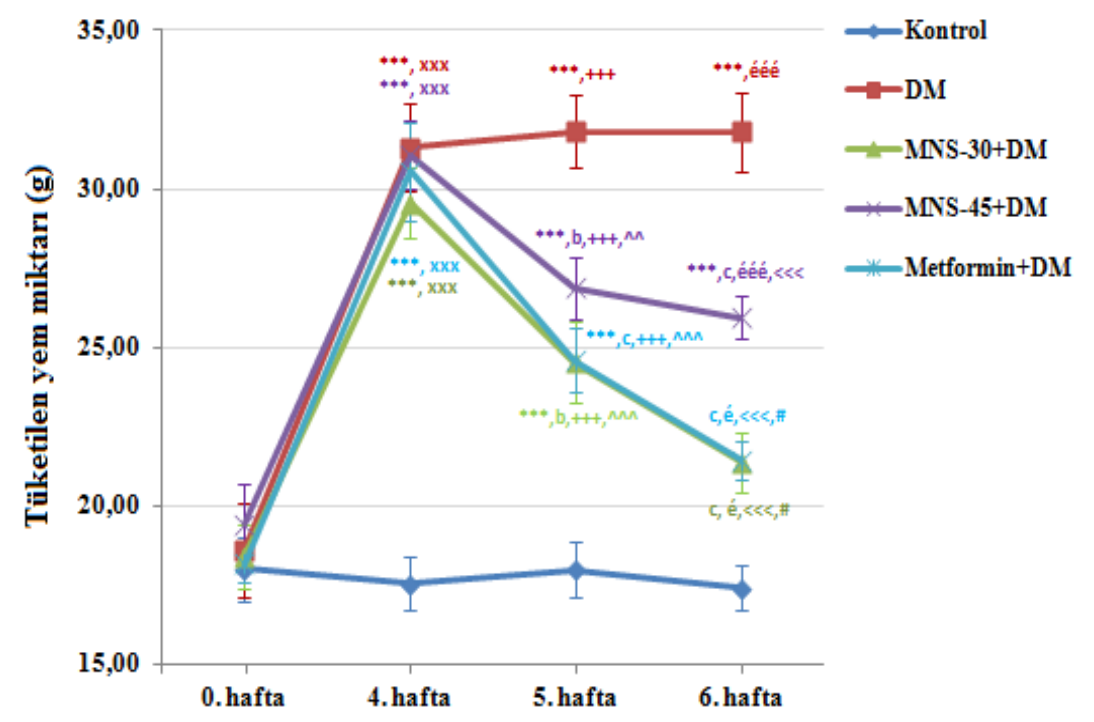

Şekil 5. Serum fizyolojik uygulanan normoglisemik (Kontrol) ve serum fizyolojik (DM), $1 \mathrm{~g} / \mathrm{kg}$ metformin (Metformin+DM), $30 \mathrm{mg} / \mathrm{kg}$ mianserin (MNS-30+DM) ve $45 \mathrm{mg} / \mathrm{kg}$ mianserin (MNS-45+DM) uygulanan diyabetik sıçanların yem tüketim değerleri,

0 . haftaya göre anlamlı farklılık ${ }^{* * *} p<0.001 ; 4$. haftaya göre anlamlı farklılık ${ }^{\mathrm{b}} p<0.01,{ }^{\mathrm{c}} p<0.001 ; 4$. hafta kontrol grubuna göre anlaml farklılık ${ }^{\operatorname{xx}} p<0.001 ; 5$. hafta kontrol grubuna göre anlamlı farklılık ${ }^{+++} p<0.001 ; 6$. hafta kontrol grubuna göre anlamlı farklılık é $p<0.05$, éée $p<0.001$; 5. hafta DM grubuna göre anlamlı farklılık ${ }^{\wedge} p<0.01,{ }^{\wedge \wedge} p<0.001 ; 6$. hafta DM grubuna göre anlamlı farklılık $<<<<0.001 ; 6$. hafta MNS-45 grubuna göre anlamlı farklılık ${ }^{\#} p<0.05$, Çift yönlü tekrarlı varyans analizi, takiben Bonferroni çoklu karşılaştırma testi, $\mathrm{n}=7$.

\section{Dışkı atılımına ilişkin bulgular}

7 ve 14 gün boyunca her gün düzenli olarak 30 ve 45 $\mathrm{mg} / \mathrm{kg}$ mianserin uygulanan normoglisemik sıçanların dışkı atılım değerleri, serum fizyolojik uygulanan normoglisemik sıçanların dışkı atılım değerlerinden farklı bulunmamıştır. Çift yönlü tekrarlı varyans analizi sonuçları sıçanların dışkı atılım değerleri üzerinde ne tedavi faktörünün $[\mathrm{F}$ $(6,54)=0.63, \mathrm{P}>0.05]$ ne de zaman faktörünün $[\mathrm{F}$ $(6,54)=0.72, \quad \mathrm{P}>0.05] \quad$ etkili olmadığını ortaya koymuştur. Ayrıca, tedavi ile zaman arasında anlamlı bir etkileşim de bulunmamaktadır $[F(6,54)=0.91$, $\mathrm{P}>0.05$ ] (Tablo 1).Şekil 6, 14 gün boyunca her gün düzenli olarak serum fizyolojik uygulanan normoglisemik (kontrol) ve serum fizyolojik, $1 \mathrm{~g} / \mathrm{kg}$ metformin, $30 \mathrm{mg} / \mathrm{kg}$ mianserin ve $45 \mathrm{mg} / \mathrm{kg}$ mianserin uygulanan diyabetik sıçanların dışkı atılım değerlerini göstermektedir. Çift yönlü tekrarlı varyans analizi sonuçları sıçanların dışkı atılım değerleri üzerinde hem tedavi faktörünün $[\mathrm{F}$ $(12,90)=19.54, \mathrm{P}<0.001]$ hem de zaman faktörünün $[\mathrm{F}(12,90)=144.6, \mathrm{P}<0.001]$ etkili olduğunu ortaya koymaktadır. Ayrica, tedavi ile zaman arasında anlamlı bir etkileșim bulunmaktadır [F $(12,90)=15.34, \mathrm{P}<0.001]$

Çoklu karşılaştırma için uygulanan Bonferroni testi, diyabet (DM), $1 \mathrm{~g} / \mathrm{kg}$ metformin uygulanmıs diyabet (Metformin+DM), $30 \mathrm{mg} / \mathrm{kg}$ mianserin uygulanmış diyabet (MNS-30+DM) ve $45 \mathrm{mg} / \mathrm{kg}$ mianserin uygulanmış diyabet (MNS-45+DM) gruplarında 
bulunan hayvanların STZ uygulamasinı izleyen 4. haftada ölçülen dışkı atılım değerlerinin, 0. hafta değerlerine göre anlamlı biçimde arttığını göstermiştir. Diyabetik sıçanlarda dışk1 atılımında görülen artış, referans madde olarak kullanılan metformin'in $(1 \mathrm{~g} / \mathrm{kg}) 7$ ve 14 günlük subakut uygulamaları ile anlamlı ölçüde azalmıştır. Metformin'in yan sira mianserin'in 30 ve $45 \mathrm{mg} / \mathrm{kg}$ dozlarının 7 ve 14 günlük subakut uygulamaları da diyabetik sıçanların 4. haftadaki yüksek dişkı atılım değerlerini istatistiksel olarak anlamlı ölçüde azaltmıştır (Şekil 6).

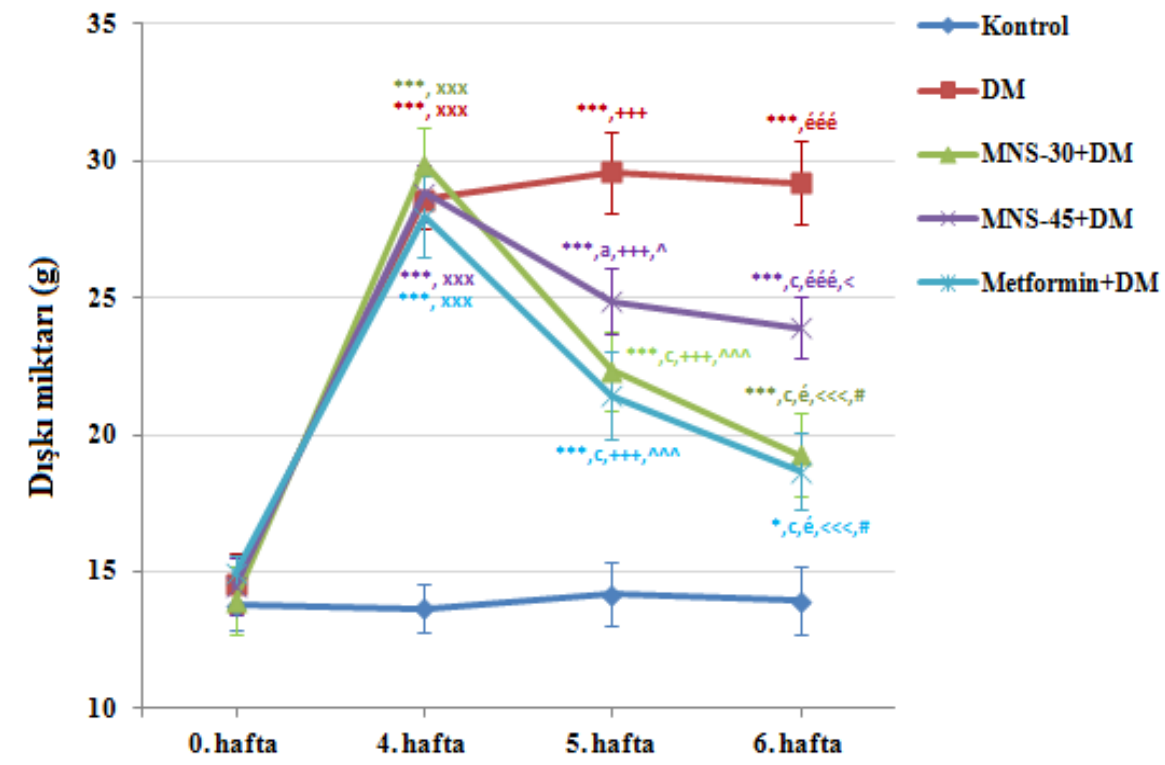

Şekil 6. Serum fizyolojik uygulanan normoglisemik (Kontrol) ve serum fizyolojik (DM), $1 \mathrm{~g} / \mathrm{kg}$ metformin (Metformin+DM), $30 \mathrm{mg} / \mathrm{kg}$ mianserin (MNS-30+DM) ve $45 \mathrm{mg} / \mathrm{kg}$ mianserin (MNS-45+DM) uygulanan diyabetik sıçanların dışkı atılım değerleri,

0 . haftaya göre anlamlı farkl1lık ${ }^{*} p<0.05,{ }^{* * *} p<0.001 ; 4$. haftaya göre anlamlı farkl1lık ${ }^{a} p<0.05,{ }^{\mathrm{c}} p<0.001 ; 4$. hafta kontrol grubuna göre

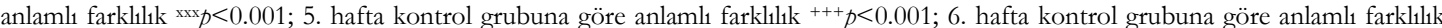
é $p<0.05$, éé $p<0.001$; 5. hafta DM grubuna göre anlamlı farkl1lık ${ }^{\wedge} p<0.05,{ }^{\wedge} p<0.001$; 6 . hafta DM grubuna göre anlamlı farkl1lik $<p<0.05,<<p<0.001 ; 6$. hafta MNS-45 grubuna göre anlamlı farklılık ${ }^{\#} p<0.05$, Çift yönlü tekrarlı varyans analizi, takiben Bonferroni çoklu karşılaştırma testi, $\mathrm{n}=7$.

\section{Vücut ağırlıklarına ilişkin bulgular}

7 ve 14 gün boyunca her gün düzenli olarak 30 ve 45 $\mathrm{mg} / \mathrm{kg}$ mianserin uygulanan normoglisemik sıçanların vücut ağırlıkları, serum fizyolojik uygulanan kontrol grubu normoglisemik sıçanların vücut ağırlıklarından farklı bulunmamıştır. Çift yönlü tekrarlı varyans analizi sonuçları sıçanların vücut ağırlı̆̆1 üzerinde tedavi faktörünün $[\mathrm{F}(6,54)=0.03$, P>0.05] etkili olmadığını ortaya koymaktadır. Diğer yandan, zaman faktörünün vücut ağırlı̆̆1 üzerinde anlamlı etki gösterdiği belirlenmiştir $[\mathrm{F}(6,54)=6.06$, $\mathrm{P}<0.01]$. Tedavi ile zaman faktörleri arasinda anlamlı bir etkileşim bulunmamaktadır $[\mathrm{F} \quad(6,54)=0.19$, $\mathrm{P}>0.05]$. Çoklu karşılaştırma için uygulanan Bonferroni testi, kontrol grubunda bulunan sıçanların vücut ağırlıklarının 14 gün içerisinde başlangıç değerlerine göre anlamlı bir biçimde arttığını ortaya koymuştur (Tablo 1). Şekil 7, 14 gün boyunca her gün düzenli olarak serum fizyolojik uygulanan normoglisemik (kontrol) ve serum fizyolojik, $1 \mathrm{~g} / \mathrm{kg}$ metformin, $30 \mathrm{mg} / \mathrm{kg}$ mianserin ve $45 \mathrm{mg} / \mathrm{kg}$ mianserin uygulanan diyabetik sıçanların vücut ağırlıklarının değişimini göstermektedir. Çift yönlü tekrarlı varyans analizi sonuçları sıçanların vücut ağırlı̆ğ değerleri üzerinde hem tedavi faktörünün $[\mathrm{F}(12,90)=8.76, \quad \mathrm{P}<0.001]$ hem de zaman faktörünün $[\mathrm{F}(12,90)=51.65, \mathrm{P}<0.001]$ etkili olduğunu ortaya koymaktadır. Ayrıca, tedavi ile zaman arasında anlamlı bir etkileşim bulunmaktadır $[\mathrm{F}(12,90)=9.12, \mathrm{P}<0.001]$.

Çoklu karşılaştırma için uygulanan Bonferroni testi diyabet (DM), $1 \mathrm{~g} / \mathrm{kg}$ metformin uygulanmıs diyabet 
(Metformin+DM), $30 \mathrm{mg} / \mathrm{kg}$ mianserin uygulanmış diyabet (MNS-30+DM) ve $45 \mathrm{mg} / \mathrm{kg}$ mianserin uygulanmış diyabet (MNS-45+DM) gruplarında bulunan hayvanların 4. hafta ölçülen vücut ağırlığ1 değerlerinin 0. hafta değerlerine göre anlamlı biçimde azaldığını göstermiştir. Diyabetik sıçanlarda vücut ağırlıklarında görülen azalma, referans madde olarak kullanılan metformin'in $(1 \mathrm{~g} / \mathrm{kg}) 7$ ve 14 günlük subakut uygulamaları ile anlamlı ölçüde düzelmiştir. Metformin'in yanı sıra mianserin'in 30 ve $45 \mathrm{mg} / \mathrm{kg}$ dozlarının 14 günlük subakut uygulamaları da diyabetik sıçanların 4. haftadaki azalmış vücut ağırlıklarını istatistiksel olarak anlamlı ölçüde arttırmıştır (Şekil 7).



Şekil 7. Serum fizyolojik uygulanan normoglisemik (Kontrol) ve serum fizyolojik (DM), $1 \mathrm{~g} / \mathrm{kg}$ metformin (Metformin+DM), $30 \mathrm{mg} / \mathrm{kg}$ mianserin (MNS-30+DM) ve $45 \mathrm{mg} / \mathrm{kg}$ mianserin (MNS-45+DM) uygulanan diyabetik sıçanların vücut ağırlıkları,

0 . haftaya göre anlamlı farklılık ${ }^{* *} p<0.01,{ }^{* * *} p<0.001 ; 4$. haftaya göre anlamlı farklılık ${ }^{\mathrm{b}} p<0.01,{ }^{c} p<0.001 ; 4$. hafta kontrol grubuna göre anlamlı farklılık $\operatorname{xxx}<<0.001 ; 5$. hafta kontrol grubuna göre anlamlı farklılık ${ }^{++} p<0.01,{ }^{+++} p<0.001 ; 6$. hafta kontrol grubuna göre anlamlı farklılık é $p<0.05$, ée $p<0.01$, éé $p<0.001$; 5. hafta DM grubuna göre anlamlı farklılık ^ $p<0.05$; 6 . hafta DM grubuna göre anlamlı farklılık $<p<0.05,<p<0.01, \ll<p<0.001$, Çift yönlü tekrarlı varyans analizi, takiben Bonferroni çoklu karşılaştırma testi, $\mathrm{n}=7$.

\section{Hemoglobin A1c değerlerinin ölçümüne ilişkin bulgular}

Şekil 8'de bilinen standart konsantrasyonlar $(0,1.25$, $2.5,5,10,20,40,80 \mathrm{ng} / \mathrm{ml}$ ) ile çizilen standart HbA1c grafiği verilmiştir. 14 gün boyunca her gün düzenli olarak serum fizyolojik uygulanan normoglisemik (kontrol) ve serum fizyolojik, $1 \mathrm{~g} / \mathrm{kg}$ metformin, $30 \mathrm{mg} / \mathrm{kg}$ ve $45 \mathrm{mg} / \mathrm{kg}$ mianserin uygulanan diyabetik sıçanların kanlarındaki $\mathrm{HbA} 1 \mathrm{c}$ miktarları çizilen bu standart grafiğe göre $\mathrm{ng} / \mathrm{mL}$ olarak hesaplanmıştır. Tablo 2, 14 gün boyunca her gün düzenli olarak serum fizyolojik uygulanan normoglisemik (kontrol) ve serum fizyolojik, $1 \mathrm{~g} / \mathrm{kg}$ metformin, $30 \mathrm{mg} / \mathrm{kg}$ mianserin ve $45 \mathrm{mg} / \mathrm{kg}$ mianserin uygulanan diyabetik sıçanların, standart grafik kullanilarak hesaplanan HbA1c miktarlarını göstermektedir $[\mathrm{F}(4,34)=41.09, \mathrm{P}<0.001]$. Tukey HSD çoklu karşılaştırma testi sonuçları diyabetik sıçanların HbA1c miktarlarının, normoglisemik sıçanlara göre anlamlı biçimde arttığını göstermiştir. Diyabetik hayvanlarda artan HbA1c değerleri gerek metformin $(1 \mathrm{~g} / \mathrm{kg})$, gerekse mianserin (hem 30 hem de $45 \mathrm{mg} / \mathrm{kg}$ ) uygulamalarına bağlı olarak anlamlı ölçüde azalmıştır. 




Şekil 8. Standart HbA1c grafiği

Tablo 2. 14 günlük uygulamaların bitiminde serum fizyolojik uygulanan normoglisemik (Kontrol) ve serum fizyolojik (DM), $1 \mathrm{~g} / \mathrm{kg}$ metformin (Metformin+DM), $30 \mathrm{mg} / \mathrm{kg}$ mianserin (MNS-30+DM) ve $45 \mathrm{mg} / \mathrm{kg}$ mianserin (MNS-45+DM) uygulanan diyabetik sıçanların HbA1c miktarları,

\begin{tabular}{|l|c|}
\hline \multicolumn{1}{|c|}{ Gruplar } & HbA1c Miktarlar1 (ng/ml) \\
\hline Kontrol (normoglisemik) & $24.40 \pm 2.44$ \\
\hline DM & $75.25 \pm 3.22^{* * *}$ \\
\hline Metformin+DM & $56.11 \pm 2.60^{* * *, c}$ \\
\hline MNS-30+DM & $51.04 \pm 3.31^{* * *, c}$ \\
\hline MNS-45+DM & $60.56 \pm 2.82^{* *,, b}$ \\
\hline
\end{tabular}

Kontrol grubuna göre anlamlı farklllık ${ }^{* * *} \mathrm{p}<0.001$; Diyabetik gruba göre anlamlı farklllık ${ }^{\mathrm{b}} \mathrm{p}<0.01,{ }^{\mathrm{c}} \mathrm{p}<0.001$. Tek yönlü varyans analizi, takiben Tukey çoklu karşılaşıtırma testi, $\mathrm{n}=7$

\section{Pankreas dokusunda INS-1 mRNA ekspresyonlarına ilişkin bulgular}

Deney gruplarına ait İns1 ve Actb genlerinin RTPCR amplifikasyon eğrisi Şekil 9'de verilmiştir. Tablo 3, 14 gün boyunca her gün düzenli olarak serum fizyolojik uygulanan normoglisemik (kontrol), serum fizyolojik uygulanan diyabetik ve $30 \mathrm{mg} / \mathrm{kg}$ mianserin uygulanan diyabetik siçanlarda İns1 ve Actb genlerin RT-PCR sonunda elde edilen eşik değerlerini göstermektedir.RT-PCR analiz sonuçlar1, diyabetik sıçanların İns1 mRNA ekspresyon düzeylerinin normoglisemik sıçanlara göre anlamlı biçimde azaldığına işaret etmiştir. Diyabetik hayvanlarda azalan Ins1 geni CP değerleri mianserin (30 mg/kg) uygulamalarına bağlı olarak artmıştır. İns-1 mRNA ekspresyon düzeyi mianserin verilen diyabetik hayvanlarda kontrole göre 15 kat artış göstermiştir (Tablo 3).

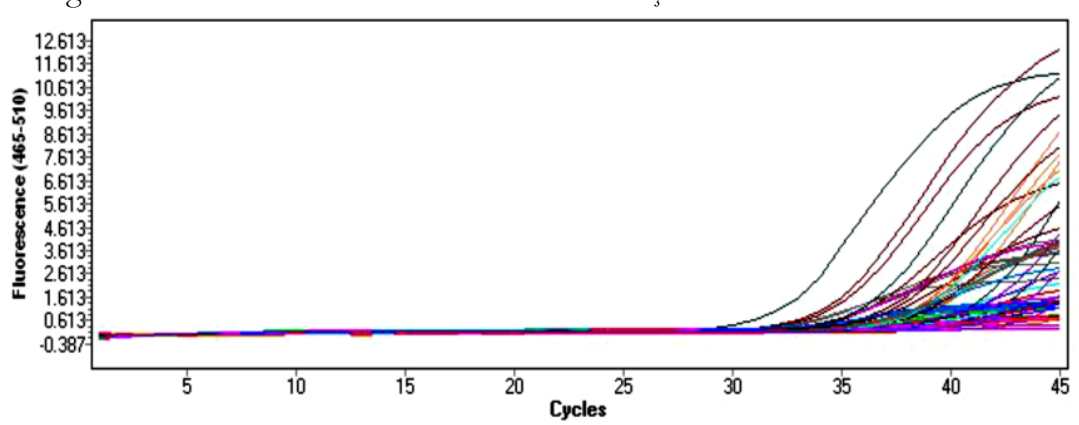

Şekil 9. İns1 ve Actb genlerinin RT-PCR amplifikasyon eğrisi. 
Tablo 3. Örnek ve referans genlerin RT-PCR sonunda elde edilen eşik değerleri (CP)

\begin{tabular}{|l|c|c|}
\hline \multicolumn{1}{|c|}{ Gruplar } & Target/Referans & Normalize Değerler \\
\hline Kontrol (normoglisemik) & 6.103 & 1.000 \\
\hline DM & 0.9629 & 0.1578 \\
\hline MNS-30+DM & 92.35 & 15.13 \\
\hline
\end{tabular}

\section{TARTIŞMA}

STZ seçici olarak pankreatik $\beta$ hücrelerinde hasara, dolayısıyla hipoinsülinemiye ve hiperglisemiye neden olan bir toksindir ${ }^{24}$. Kemirgenlere STZ uygulanmas1 ile oluşan hiperglisemik tablo deneysel bir diyabet modeli olarak siklıkla kullanılmaktadır ${ }^{25}$. STZ, vücuttan hızla atıldığ1 için diyabetik hayvanlarda görülen farklılıkların STZ'den değil, diyabetin kendisinden kaynaklandığ 1 kabul edilmektedir ${ }^{26}$.

Çalışmamızda STZ uygulamasını izleyen 4. haftada ölçülen kan glukoz değerlerinin 0 . hafta kan glukoz değerlerine göre anlamlı biçimde arttı̆̆ görülmektedir (Şekil 1). Bu bulgu, STZ-aracılıklı diyabet modelinin başarılı biçimde oluşturulduğunu ortaya koymaktadır. Bu çalışmada açlık kan glukoz değerlerine ilişkin olarak elde edilen veriler, mianserin'in normoglisemik sıçanların glisemi değerlerini etkilemediğini ortaya koymuştur (Tablo 1). Diğer yandan diyabetik sıçanların artmış kan glukoz seviyeleri gerek metformin, gerekse mianserin (30 ve $45 \mathrm{mg} / \mathrm{kg}$ ) uygulamaları ile anlaml ölçüde azalmıştır. Mianserin'in $30 \mathrm{mg} / \mathrm{kg}$ dozunun 14 günlük uygulanmasının 7 günlük uygulamadan daha etkili olduğu dikkati çekmektedir. Ayrıca, 14 günlük uygulamaların sonuçları değerlendirildiğinde, mianserin'in $30 \mathrm{mg} / \mathrm{kg}$ dozunun diyabetik sıçanların kan glukozunu düşürmekte $45 \mathrm{mg} / \mathrm{kg}$ 'dan daha etkili olduğu belirlenmiştir. Öyle ki, mianserin'in 30 $\mathrm{mg} / \mathrm{kg}$ dozu, kan glukozunu düşürmekte metformin $(1 \mathrm{~g} / \mathrm{kg}$ ) kadar etkili bulunmuştur (Şekil 1).

OGTT testine ilişkin veriler diyabetik hayvanların glukoz yüklemesini takiben 0., 30., 60., 90. ve 120. dakikalarda ölçülen kan glukoz değerlerinin, karşılık gelen kontrol grubu değerlerinden anlamlı biçimde yüksek olduğuna işaret etmiştir. Metformin ve mianserin (30 ve $45 \mathrm{mg} / \mathrm{kg}$ ) tedavisi almış olan hayvanların 0., 30., 60., 90. ve 120. dakikalarda ölçülen kan glukoz değerlerinin, DM grubuna göre düşük olması, gerek metformin'in gerekse mianserin'in diyabetik sıçanların glisemik kontrolü üzerine olumlu etki gösterdiği şeklinde yorumlanabilir. Bu çalışmada, $30 \mathrm{mg} / \mathrm{kg}$ mianserin uygulanan grubun 30 . ve 60 . dakikalarda ölçülen kan glukoz değerleri, $45 \mathrm{mg} / \mathrm{kg}$ mianserin uygulanan grubun söz konusu dakikalarda ölçülen kan glukoz değerlerinden anlamlı ölçüde düşük bulunmuştur. OGTT sonuçları değerlendirildiğinde, metformin uygulanan grup ile $30 \mathrm{mg} / \mathrm{kg}$ mianserin uygulanan grup arasında hiçbir dakikada anlamlı bir fark oluşmadığ1 görülmüştür (Şekil 2).

Açlık kan glukoz değerlerine ilişkin bulgular, OGTT'ye ilişkin bulgular ile birlikte değerlendirildiğinde, mianserin'in hem 30 hem de 45 $\mathrm{mg} / \mathrm{kg}$ dozlarda subakut uygulamasının diyabetik hayvanların yüksek kan glukoz seviyelerinde düşüşe neden olduğu sonucuna ulaşılmaktadır. Mianserin’in normoglisemik hayvanların kan glukoz seviyeleri üzerine anlamlı bir etki göstermeksizin (Tablo 1) diyabetik hayvanların yüksek kan glukoz seviyelerinde düşüşe neden olması (Şekil 1 ve 2), söz konusu etkinin diyabetik koşullarda ortaya çıkan "antihiperglisemik" bir etki olduğuna işaret etmektedir. Bu bulgu mianserin kullanan diyabetik hastalarda glisemik kontrolün etkilenmesi açısından anlamlı olabilir. Ayrıca, antihiperglisemik etkinlik açısından mianserin'in $30 \mathrm{mg} / \mathrm{kg}$ dozunun $45 \mathrm{mg} / \mathrm{kg}$ dozundan daha etkili olması, mianserin'in antihiperglisemik etkisinin bifazik olabileceğini düşündürmektedir.

$\mathrm{Bu}$ çalışmanın ikinci basamağında, subakut mianserin uygulamasının gerek normoglisemik gerekse diyabetik hayvanların metabolik parametreleri üzerine etkisinin araştırılması amacıyla, metabolik kafes ölçümleri yapılmıştır. Metabolik kafes ölçümlerine ilişkin bulgular, mianserin'in normoglisemik sıçanların yem ya da su tüketimi üzerinde her hangi bir etkiye neden olmadığını ortaya koymuştur. Benzer biçimde, mianserin uygulanmış normoglisemik hayvanların idrar ya da dışkı atılımında, tedavi uygulanmamış hayvanlara göre anlamlı bir fark oluşmamıştır (Tablo 1).

Diğer yandan, STZ enjeksiyonunu izleyen 4. hafta yapılan ölçümlerde, diyabetik sıçanların su tüketimlerinin anlamlı biçimde arttığ1 görülmüştür (Şekil 3). Polidipsi"nin diyabetik hayvanlarda hiperglisemiye bağlı olarak hücre içi ve hücre diş1 dehidratasyon ve yüksek miktarlarda su kaybı 
sonucu oluştuğu bilinmektedir ${ }^{27}$. Bu çalışmada, gerek metformin gerekse mianserin (30 ve 45 $\mathrm{mg} / \mathrm{kg}$ ) uygulamaları diyabetik sıçanlardaki polidipsi'yi anlamlı ölçüde azaltmıştır. Mianserin'in $30 \mathrm{mg} / \mathrm{kg}$ dozunun 14 günlük uygulanmasinın 7 günlük uygulamadan daha etkili olduğu dikkati çekmektedir. 14 günlük uygulamaların sonuçları değerlendirildiğinde, mianserin'in $30 \mathrm{mg} / \mathrm{kg}$ dozunun diyabetik polidipsiyi düzetmekte 45 $\mathrm{mg} / \mathrm{kg}$ 'dan daha etkili olduğu belirlenmiştir. Mianserin'in $30 \mathrm{mg} / \mathrm{kg}$ dozu, artmış su tüketimini düzeltmekte metformin (1 $\mathrm{g} / \mathrm{kg}$ ) kadar etkili bulunmuştur.

Çalışmamızda, diyabetik hayvanlarda polidipsi ile birlikte poliürinin de geliştiği görülmüştür (Şekil 4). Diyabette hipergliseminin ve hücre dışı sıvılardaki artmış ozmotik basıncın, hücre içerisindeki suyun ozmotik olarak hücre dişına taşınmasına, yani hücrelerde dehidratasyona neden olduğu bilinmektedir. Glukozun ozmotik etkisi renal tübüllerde sıvıların tübüler geri emilimini büyük oranda azaltmakta ve idrarla yüksek ölçüde sıvı kaybedilmektedir ${ }^{28}$. Bu çalışmada, gerek metformin gerekse mianserin (30 ve $45 \mathrm{mg} / \mathrm{kg}$ ) uygulamaları diyabetik sıçanlarda ortaya çıkan poliüri tablosunu anlamlı biçimde düzeltmiştir. Mianserin'in $30 \mathrm{mg} / \mathrm{kg}$ dozunun 14 günlük uygulanmasının 7 günlük uygulamadan daha etkili olduğu dikkati çekmektedir. Ayrıca, 14 günlük uygulamaların sonuçları değerlendirildiğinde, mianserin'in $30 \mathrm{mg} / \mathrm{kg}$ dozunun diyabetik sıçanlardaki poliüriyi düzeltmekte $45 \mathrm{mg} / \mathrm{kg}$ 'dan daha etkili olduğu belirlenmiştir. Mianserin $30 \mathrm{mg} / \mathrm{kg}$ dozda, metformin (1 g/ $\mathrm{kg}$ ) kadar etkili bulunmuştur (Şekil 4).

STZ enjeksiyonunu izleyen 4. hafta yapilan ölçümlerde, diyabetik sıçanların yem tüketimlerinin de anlamlı biçimde arttığı görülmüştür (Şekil 5). Diyabetik hayvanlardaki hiperfajinin santral sinir sisteminde besin alımı ve enerji metabolizmasını düzenlemekte görevli hormonlar olan, insülinin ve leptinin miktarlarındaki azalma ile ilişkili olabileceği ileri sürülmüştür ${ }^{29-31}$. Gerek metformin gerekse mianserin (30 ve $45 \mathrm{mg} / \mathrm{kg}$ ) uygulamaları diyabetik sıçanlardaki hiperfajiyi anlamlı biçimde azaltmıştır. 14 günlük uygulamaların sonuçları değerlendirildiğinde, mianserin'in $30 \mathrm{mg} / \mathrm{kg}$ dozunun diyabetik hiperfajiyi düzeltmekte 45 $\mathrm{mg} / \mathrm{kg}$ 'dan daha etkili olduğu belirlenmiştir. Mianserin $30 \mathrm{mg} / \mathrm{kg}$ dozda hiperfajiyi düzeltmekte metformin $(1 \mathrm{~g} / \mathrm{kg}$ ) kadar etkili bulunmuştur (Şekil $5)$.
Çalışmamızda, diyabetik hayvanlarda hiperfaji ile birlikte dışkı atılımlarının da arttı̆̆1 görülmüştür (Şekil 6). Diyabetik hayvanların dışkı miktarlarındaki artışın hiperfajinin yanı sıra insülin eksikliği nedeniyle tüketilen besinin vücut tarafindan kullanılamamasına bağlı olması olası görünmektedir. Diyabetik sıçanlardaki dışkı artışı, metformin ve mianserin (30 ve $45 \mathrm{mg} / \mathrm{kg}$ ) uygulamaları sonucu anlamlı biçimde azalmıştır. 14 günlük uygulamaların sonuçları değerlendirildiğinde, mianserin'in 30 $\mathrm{mg} / \mathrm{kg}$ dozunun dişkı artışını azaltmakta 45 $\mathrm{mg} / \mathrm{kg}$ 'dan daha etkili olduğu belirlenmiştir. Mianserin $30 \mathrm{mg} / \mathrm{kg}$ dozda metformin (1 g/ $/ \mathrm{kg}$ ) kadar etkili bulunmuştur (Şekil 6).

Metabolik kafes ölçümlerinden elde edilen bulgular toparlandığında, diyabet oluşturulmuş sıçanlarda polidipsi, poliüri ve hiperfaji geliştiği görülmüştür. Diyabetik hayvanların dışkı atılım miktarları hem diyabet öncesi dışkı atılım miktarlarına; hem de kontrol grubu hayvanların karşılık gelen haftadaki dışkı atılım miktarlarına göre anlamlı biçimde artmıştır. Referans ilaç olarak uygulanan metformin $1 \mathrm{~g} / \mathrm{kg}$ dozda ve etkisi araştırılan mianserin 30 ve 45 $\mathrm{mg} / \mathrm{kg}$ dozlarda diyabetik hayvanlarda meydana gelen metabolik bozuklukları istatistiksel olarak anlamlı biçimde düzeltmiştir. Diğer yandan, normoglisemik hayvanlarda yapılan ölçümler, mianserin'in normoglisemik sıçanların su ve yem tüketimini; idrar ve dışkı atılımını değiştirmediğini ortaya koymuştur.

STZ enjeksiyonunu izleyen 4. hafta yapılan ölçümlerde, diyabetik sıçanların, normoglisemik sıçanlara göre önemli ölçüde zayıfladıkları görülmüştür. Diyabetik hayvanlarda vücut ağırlığındaki azalma, vücudun insülin eksikliği nedeniyle besin ögelerinden yararlanamaması ile ilgilidir. Gerek metformin gerekse mianserin uygulamaları diyabetik sıçanların vücut ağırlığındaki azalmayı anlamlı ölçüde düzeltmiştir (Şekil 7).

Mianserin'in normoglisemik hayvanların metabolik parametrelerini (Tablo 1) ya da vücut ağırlıklarını etkilemeksizin (Tablo 1) yalnızca diyabetik hayvanların bozulmuş metabolik parametrelerini düzeltici (Şekil 3-6) ve ağırlık kayıplarını azaltıcı (Şekil 7) etki göstermesi, bu ilacın diyabetik hayvanlardaki antihiperglisemik etkinliği ile ilişkili gibi görünmektedir. Nitekim mianserin'in kan glukozunu düşürmekte daha etkin olan $30 \mathrm{mg} / \mathrm{kg}$ dozu, metabolik parametreleri düzeltmek açısından da $45 \mathrm{mg} / \mathrm{kg}$ dozundan daha etkin bulunmuştur. 
Açlık kan glukoz ölçümlerinde, OGT'T'de, metabolik kafes takiplerinde ve vücut ağırlıklarına ilişkin ölçümlerde elde edilen tüm bulgular, mianserin'in antihiperglisemik etki gösterdiğine işaret ettiğinden, deney protokolünün sonunda diyabetik sıçanlara anestezi uygulanmış, kanları toplanmış ve HbA1c miktarları ölçülmüştür. Mianserin'in her iki dozunun da referans ilaç metformine benzer biçimde diyabetik hayvanlarda artan HbA1c değerlerini anlamlı ölçüde azalttığ belirlenmiştir (Tablo 2).

Elde edilen antihiperglisemik etkiden hareketle, bu çalışmada mianserin'in insülin ekpresyonu (İns-1 mRNA ekspresyonu) üzerine herhangi bir etkisinin olup olmadığ1 da araştırılmıştır. PCR sonuçları, diyabetik siçanların İns1 mRNA ekspresyon düzeylerinin, normoglisemik sıçanlara göre anlamlı biçimde azaldığını göstermiştir. Mianserin'in antihiperglisemik etkinlik açısından daha güçlü olan $30 \mathrm{mg} / \mathrm{kg}$ 'llk dozu diyabetik hayvanlarda azalan İns1 geni CP değerlerini anlamlı ölçüde artırmıştır (Tablo 3). $\mathrm{Bu}$ bulgular mianserin'in antihiperglisemik etkisine insülin sentezindeki artışın katkıda bulunmuş olabileceğini düşündürmekle birlikte, bu düşünceyi doğrulamak ve İns1 mRNA ekspresyon analiz sonuçlarını desteklemek için İns1 protein analizleri gibi ek çalışmalara gereksinim duyulmaktadır.

Sonuç olarak, bu araştırma ile mianserin'in 30 ve 45 $\mathrm{mg} / \mathrm{kg}$ dozlarda 7 ve 14 gün süre subakut uygulamasının STZ ile diyabet oluşturulmuş sıçanlarda görülen hiperglisemiyi ve artmış HbA1c değerlerini azalttığı; diyabete bağlı olarak ortaya çıkan polidipsi, poliüri ve hiperfaji gibi metabolik parametreleri etkin biçimde düzelttiği ve vücut ağırlı̆̆ındaki kaybı anlamlı biçimde azalttığı ortaya konulmuştur. Mianserin'in metformine yakın antihiperglisemik etkinliği bu çalışma ile ilk kez ortaya konulmuştur. Mianserin'in antihiperglisemik etkisinin moleküler mekanizmalarının aydınlatılabilmesi için bu ilacın diyabetik koşullarda insülin salınımı, dokuların insüline duyarlılıkları ya da barsaklardan/böbreklerden karbonhidrat emilimi gibi işlevler üzerine olası etkilerinin kapsamlı biçimde araştırılması gerekmektedir.

\section{Teşekkür}

Bu çalşsma Anadolu Üniversitesi Bilimsel Araștırma Projeleri Komisyonu tarafindan desteklenmiştir (Proje No. 11055084).

\section{KAYNAKLAR}

1. World Health Organisation Department of Noncommunicable Disease Surveillance. Definition, diagnosis and classification of Diabetes mellitus and it's copmlications, Geneva: Published by World Health Organisation. 1999:2.

2. Tripathi BK, Srivastava AK. Diabetes mellitus: complications and therapeutics. Med Sci Monit. 2006;12:RA130-RA147.

3. Wolfsdorf J, Glaser N, Sperling MA. Diabetic ketoacidosis in infants, children, and adolescents: A consensus statement from the American Diabetes Association. Diabetes Care. 2006;29:1150-9.

4. Sima AAF, Kamiya H, Li ZG. Insulin, C-peptide, hyperglycemia, and central nervous system complications in diabetes. Eur J Pharmacol. 2004;490:187-97.

5. Craft S. Insulin resistance syndrome and Alzheimer disease: pathophysiologic mechanisms and therapeutic implications. Alzheimer Dis Assoc. Disord. 2006;20:298-301.

6. Pasquier F, Boulogne A, Leys D, Fontaine P. Diabetes mellitus and dementia. Diabetes Metab. 2006;32:403-14.

7. Shrivastava RK, Edwards D. Hypoglycemia associated with imipramine. Biol Psychiatry. 1983;18:1509-10.

8. Zogno MG, Tolfo L, Draghi E. Hypoglycemia caused by maprotiline in a patient taking oral antidiabetics. Ann Pharmacother. 1994;28:406.

9. Isotani H, Kameoka K. Hypoglycemia associated with maprotiline in a patient with type I diabetes. Diabetes Care 1999;22:862-63.

10. Lustman PJ, Freedland KE, Griffith LS, Clouse RE. Fluoxetine for depression in diabetes: a randomized double-blind placebo-controlled trial. Diabetes Care. 2000;23:618-23.

11. Lustman PJ, Griffith LS, Clouse RE, Freedland KE, Eisen SA, Rubin EH et al. Effects of nortriptyline on depression and glycaemic control in diabetes: results of a double-blind, placebo-controlled trial. Psychosom Med. 1997;59:241-50.

12. McIntyre RS, Soczynska JK, Konarski JZ, Kennedy SH. The effect of antidepressants on glucose homeostasis and insulin sensitivity: synthesis and mechanisms. Expert Opin Drug Saf. 2006;5:157-68.

13. Marshall RJ. The pharmacology of mianserin. An update. Br J Clin Pharmacol. 1983;15:263-8.

14. Pinder RM. Adrenoreceptor interactions of the enantiomers and metabolites of mianserin: are they responsible for the antidepressant effect ? Acta Psychiatr Scand. 1985;72:1-9.

15. Schreiber S, Backer MM, Kaufman JP, Pick CG. Interaction between the tetracyclic antidepressant mianserin $\mathrm{HCl}$ and opioid receptors. Eur. Neuropsycopharmacol. 1998;8:297-302. 
16. Pakulska W, Czarnecka E. Influence of mianserin on the antinociceptive effect of morphine, metamizol and indomethacin in mice. Pharmacol Res. 2002;46:415-23.

17. Pospisilik JA, Martin J, Doty T, Ehses JA, Pamir N, Lynn FC et al. Dipeptidyl peptidase IV inhibitor treatment stimulates beta-cell survival and islet neogenesis in streptozotocin-induced diabetic rats. Diabetes. 2003;52:741-50.

18. Skalska S, Kyselova Z, Gajdosikova A, Karasu C, Stefek M, Stolc S. Protective effect of stobadine on NCV in streptozotocin-diabetic rats: augmentation by vitamin E. Gen. Physiol Biophys. 2008;27:106-14.

19. Can ÖD, Öztürk Y, Öztürk N, Sagratini G, Ricciutelli M, Vittori S et al. Effects of treatment with St. John's Wort on blood glucose levels and pain perceptions of streptozotocin-diabetic rats. Fitoterapia. 2011;82:576-84.

20. Drenska D, Varadinova M, Boyadjieva N, BozhilovaPastirova A. Effect of anthocyanins and mianserin on neuronal density in rat hippocampus in a model of oxidative stress. Pharmacology online. 2008;2:1338.

21. Ong KW, Hsu A, Song L, Huang D, Tan BK. Polyphenols-rich Vernonia amygdalina shows antidiabetic effects in streptozotocin-induced diabetic rats. J Ethnopharmacol. 2011;133:598-607.

22. Vijayaraghavan K, Iyyam Pillai S, Subramanian SP. Design, synthesis and characterization of zinc-3 hydroxy flavone, a novel zinc metallo complex for the treatment of experimental diabetes in rats. Eur J Pharmacol. 2012;680:122-9.

23. Gupta S, Rifici V, Crowley S, Brownlee M, Shan Z, Schlondorff D. Interactions of LDL and modified
LDL with mesangial cells and matrix. Kidney Int. 1992:41:1161-9.

24. Rakieten N, Rakieten L, Nadkarni MV. Studies on the diabetogenic action of streptozotocin. Cancer Chemother Rep. 1963;29:91-8.

25. Sumiyoshi T, Ichikawa J, Meltzer HY. The effect of streptozotocin-induced diabetes on dopamine[2], serotonin[1A] and serotonin[2A] receptors in the rat brain. Neuropsychopharmacology 1997;16:183-90.

26. Hirano S, Miyata S, Onodera K, Kamei J. Effects of histamine $\mathrm{H}(1)$ receptor antagonists on depressivelike behavior in diabetic mice. Pharmacol Biochem. Behav. 2006;83:214-20.

27. Hall JE Guyton and Hall Textbook of Medical Physiology. 12th ed., Philadelphia, Saunders Elsevier. 2011.

28. Kim D, Sands JM, Klein JD. Role of vasopressin in diabetes mellitus-induced changes in medullary transport proteins involved in urine concentration in Brattleboro rats. Am J Physiol Renal Physiol. 2004;286:760-6.

29. Havel PJ, Uriu-Hare JY, Liu T, Stanhope KL, Stern JS, Keen CL, Ahren B. Rapid and marked decreases of circulating leptin in streptozotocin diabetic rats: reversal by insulin. Am J Physiol. 1998;274:1482-91.

30. Sivitz WI, Walsh S, Morgan D, Donohue P, Haynes W, Leibel RL. Plasma leptin in diabetic and insulintreated diabetic and normal rats. Metabolism. 1998;47:584-91.

31. Barber M, Kasturi BS, Austin ME, Patel KP, MohanKumar SM, MohanKumar PS. Diabetesinduced neuroendocrine changes in rats: role of brain monoamines, insulin and leptin. Brain Res. 2003;964:128-35 